\title{
Comparative Study on A Novel Pathogen of European Seabass. Diversity of Aeromonas veronii in the Aegean Sea
}

\author{
Maria Smyrli ${ }^{1,2}$, Adriana Triga ${ }^{1,2}$, Nancy Dourala ${ }^{3}$, Panos Varvarigos ${ }^{4}$, Michael Pavlidis ${ }^{2}$, \\ Viet Ha Quoc ${ }^{1}$ and Pantelis Katharios ${ }^{1, *}$ D \\ 1 Institute of Marine Biology, Biotechnology and Aquaculture, Hellenic Centre for Marine Research, Heraklion, \\ 71500 Crete, Greece; msmyrli@hcmr.gr (M.S.); triga@hcmr.gr (A.T.); qvha@hcmr.gr (V.H.Q.) \\ 2 Department of Biology, University of Crete, Heraklion, 70013 Crete, Greece; pavlidis@biology.uoc.gr \\ 3 Fish Pathology Department, Selonda Aquaculture, 15125 Athens, Greece; adourala@otenet.gr \\ 4 VETCARETM, 11528 Athens, Greece; info@vetcare.gr \\ * Correspondence: katharios@hcmr.gr
}

Received: 21 August 2019; Accepted: 25 October 2019; Published: 29 October 2019

check for updates

\begin{abstract}
Aeromonas veronii is an emerging pathogen causing severe pathology and mortalities in European seabass aquaculture in the Aegean Sea, Mediterranean. More than 50 strains of the pathogen were characterized biochemically and genetically in order to study the epidemiology of the disease, as well as the phylogeny and virulence of the bacterium. Based on the phenotypic characteristics, the isolates form three groups consisting of: (a) the West Aegean Sea, non-motile, non-pigment-producing strains, (b) the West Aegean Sea, motile, and pigment-producing strains and (c) the East Aegean Sea motile strains that produce minute amounts of pigment. All strains were highly similar at the genomic level; however, the pattern of West/East geographic origin was reflected in biochemical properties, in general genomic level comparison and in the putative virulent factors studied. Type VI secretion system was not detected in the western strains. The outer membrane protein (OMP) profile which contains proteins that are putative antigenic factors, was very similar between strains from the different areas. Although most of the OMPs were detected in all strains with great sequence similarity, diversification according to geographic origin was evident in known antigenic factors such as the maltoporin LamB. A systematic comparative analysis of the strains is presented and discussed in view of the emergence of $A$. veronii as a significant pathogen for the Mediterranean aquaculture.
\end{abstract}

Keywords: Aeromonas veronii; European seabass; Aegean Sea; Mediterranean; comparative genomics; virulence; OMPs

\section{Introduction}

Mesophilic, motile Aeromonas spp. are responsible for ulcerative, hemorrhagic, and septicemic infections in freshwater and ornamental fish [1]. While A. hydrophila is the most cited, modern diagnostic tools [2] have resulted in the identification of many more species implicated in disease development including A. veronii, A. bestiarum, A. caviae, A. jandaei, A. piscicola, A. schubertii, and A. sobria. Amongst them, $A$. veronii is increasingly gaining importance as a serious pathogen for the aquaculture industry. Outbreaks accompanied by significant losses have been reported in African catfish (Clarias gariepinus), rajputi (Puntius gonionotus), rui (Labeo rohita), catla (Catla catla), and shole (Channas triatus) farmed in Bangladesh [3], in Chinese longsnout catfish (Leiocassis longirostris) [4] loach (Misgurnus anguillicaudatus), [5] and cyprinid fish [6] farmed in China and in ayu (Plecoglossus altivelis) 
farmed in Japan [7]. In addition to aquaculture, A. veronii has also been reported to cause disease in ornamental fishes [8].

During the past decade, A. veronii bv. sobria has become extremely problematic in the culture of European seabass (Dicentrarchus labrax) in Greece. The disease first appeared in 2008 affecting a single fish farm in Central Greece [9]. While it is still present in the specific farm, more farms in distant areas are also affected. At the beginning, the disease affected mainly fish reaching the commercial size $(>200 \mathrm{~g})$, but lately it has been reported to affect also younger fish with weight lower than $50 \mathrm{~g}$. Outbreaks occur during the warm months of the year, when water temperature is over $21^{\circ} \mathrm{C}$. Cumulative mortality during outbreaks reaches $>50 \%$, if it is not treated with antibiotics and it is a major concern for the producers in the affected areas.

Affected fish appear lethargic with no appetite and in progressed stages of the disease they have an icteric appearance due to the highly haemolytic nature of the pathogen. Internally, multiple abscesses are usually found in the spleen and the kidney. Interestingly, the pathogen affects exclusively the European seabass and even during severe outbreaks, other fish species like the gilthead seabream (Sparus aurata), red porgy (Pagrus pagrus), and sharpsnout seabream (Diplodus puntazzo), which are cultured in adjacent sea cages of the affected areas are not infected (personal observations).

Over the past decade, we have collected a large number of $A$. veronii strains from European seabass of Greek aquaculture farms during disease outbreaks at various time points during the year. Here, we present a comparative study of $50 \mathrm{~A}$. veronii clinical strains from different geographic areas. Biochemical diversity and phylogenetic relationships were assessed. Comparative genomic analysis was conducted to assess similarity at the genome level and to study putative virulence factors that may have contributed to pathogenicity. Pathogenicity was also tested in vivo using zebrafish as a model. We followed the principles of reverse vaccinology using the draft genomes of nine $A$. veronii strains, representatives of the geographic location, the phenotype, and the year of isolation in order to assess the antigenic diversity of the species in Greece. Through this study we identified and compared outer membrane proteins (OMPs) to establish the basis for effective strain selection for a future vaccine for seabass in the Aegean Sea. The final goal of this work was to acquire knowledge on the diversity of a novel pathogen and contribute to the management of a very important emerging disease for the Mediterranean aquaculture industry.

\section{Materials and Methods}

Localities included in the study were selected based on reports from the fish vets of the affected farms for aeromonad-suspected morbidity and mortality. Extended sampling was conducted in the area of Argolikos Bay where the disease was first described [9]. Microbial screenings on diseased fish farmed in sea-cages, were conducted at various times (2009-2019) including periods of disease outbreaks but also periods when fish showed no signs of the disease. Only the positive for Aeromonas spp. samplings are presented here. In the study we have also included samples from disease outbreaks in the ornamental freshwater fish Green swordtail (Xiphophorus helleri) farmed in North/East Greece and in zebrafish (Danio rerio) from the experimental facilities of the Biology Department of the University of Crete, Greece. Detailed information on the samplings conducted is presented in Table 1.

Samples of fish and bacteria were either collected on site or were sent and processed at the Hellenic Centre for Marine Research (HCMR). Fish underwent full necropsy and clinical signs of disease were recorded when present. Bacteria were isolated from the kidney of fish on Trypticase soy agar (TSA) (Trafalgar Scientific, Leicester, UK) supplemented with salt $(2 \% \mathrm{NaCl})$ and on the selective for Aeromonas spp. Aeromonas isolation agar (AIA) (Sigma-Aldrich, St. Louis, MO, USA) supplemented with ampicillin. Aeromonads detection was based on growth on AIA and positive PCR reaction for the 16S-23S rRNA intergenic spacer region using genus-specific primers for Aeromonas spp. [10]. Subsequently, identification to genus level was achieved by PCR amplification of the extracellular lipase Glycerophospholipid-cholesterol acyltransferase (GCAT) gene [11]. Only positive isolates (1-7 per sampling) were further analysed by random selection. For identification to species level, 
the gene of B-subunit of DNA gyrase ( $g y r \mathrm{~B})$ was amplified according to reference [12] and sequenced in ABI3730xl sequencer based on the protocol of BigDye Terminators 3.1 (Applied Biosystems, Thermo Fisher Scientific, Carlsbad, CA, USA). Sequences were deposited to GenBank under the Accession Numbers: MN193961-MN193984 and MN193987-MN194010. The obtained sequences were compared in GenBank using the NCBI BLAST algorithms. Phylogenetic analysis was conducted using the sequences of gyrB gene produced herein and sequences from all the Aeromonas spp. known up to date. Alignment was performed in Clustal W [13]. Genetic distances were estimated and phylogenetic relationships were examined with neighbor-joining (NJ) analyses [14] in MEGA X [15] under Tamura-Nei [16] model of evolution. The confidence of tree nodes was tested by the bootstrap analysis with 1000 replicates.

Table 1. The number of samplings conducted, the locations and dates of samplings, and the fish species sampled.

\begin{tabular}{|c|c|c|c|c|c|}
\hline \# Sampling & Area & Locality & Fish Farm & Fish Species & Sampling Date \\
\hline $1 *$ & \multirow{12}{*}{ West Aegean Sea } & Argolikos Bay & $1-2$ & D. labrax & 2009 [9] \\
\hline $2-3$ & & Argolikos Bay & $1-2$ & & $9 / 2015$ \\
\hline 4 & & Argolikos Bay & $1-2$ & & $11 / 2015$ \\
\hline 5 & & Argolikos Bay & $1-2$ & & $3 / 2016$ \\
\hline $6-7$ & & Argolikos Bay & $1-2$ & & $9 / 2016$ \\
\hline $8 *$ & & Argolikos Bay & $1-2$ & & $6 / 2018$ \\
\hline 9 & & Argolikos Bay & $1-2$ & & $9 / 2018$ \\
\hline 10 & & Argolikos Bay & $1-2$ & & $10 / 2018$ \\
\hline 11 & & Argolikos Bay & 3 & & $12 / 2015$ \\
\hline 12 & & Saronikos Bay & 4 & & $9 / 2016$ \\
\hline $13 *$ & & Saronikos Bay & 4 & & $5 / 2018$ \\
\hline $14^{*}$ & & Saronikos Bay & 4 & & $6 / 2018$ \\
\hline 15 & \multirow{9}{*}{ East Aegean Sea } & Agathonisi Isl. & 5 & & $4 / 2015$ \\
\hline $16^{*}$ & & Agathonisi Isl. & 5 & & $6 / 2015$ \\
\hline 17 & & Agathonisi Isl. & 5 & & $9 / 2015$ \\
\hline 18 & & Agathonisi Isl. & 5 & & $11 / 2015$ \\
\hline $19^{* *}$ & & Agathonisi Isl. & 5 & & $7 / 2016$ \\
\hline 20 * & & Kalymnos Isl. & 6 & & $6 / 2015$ \\
\hline $21-22$ & & Kalymnos Isl. & 6 & & $9 / 2015$ \\
\hline $23 *$ & & Güllück & 7 & & 2010 \\
\hline 24 * & & Bodrum & 8 & & $3 / 2019$ \\
\hline $25 *$ & \multirow{2}{*}{ Other } & N/E Greece & 9 & X. helleri & $2 / 2015$ \\
\hline $26^{*}$ & & Crete & 10 & D. rerio & $12 / 2018$ \\
\hline
\end{tabular}

*: Outbreak, **: transportation

Colony morphology was observed on TSA. Motility was tested on motility, indole, and ornithine (MIO) medium (Sigma-Aldrich). Pigment production was tested on TSA and Mueller-Hinton agar (MH) (Trafalgar Scientific, Leicester, England) after incubation for $24-72 \mathrm{~h}$, as well as their corresponding broths after incubation for $7 \mathrm{~d}$.

Biochemical characterization was conducted with the commercial kits BIOLOG GEN III Microplate (BIOLOG) (Biolog, Hayward, CA, USA) and API 20E (bioMérieux Hellas S.A, Athens, Greece). Results were recorded after $24 \mathrm{~h}$ incubation for API 20E and after $48 \mathrm{~h}$ incubation for BIOLOG. BIOLOG and API 20E were also used for identification to genus level [2]. Catalase reaction was tested separately. The TSA and MH mediums were supplemented with $0.5 \% \mathrm{NaCl}$. All tests were performed at $25^{\circ} \mathrm{C}$. The type strains LMG 3785 (A. veronii bv. sobria) and LMG 9075 (A. veronii bv. veronii) were included in all tests as reference strains. Hemolytic activity was tested on $5 \%$ seabass blood agar [17]. Fish blood was taken aseptically from healthy European seabass broodfish maintained in the aquaculture facilities of HCMR. Results were recorded at 24 and $48 \mathrm{~h}$ incubation at $25^{\circ} \mathrm{C}$. Susceptibility to antibacterial agents was assessed by the disk diffusion method [18] using 6-mm commercial disks (Oxoid, Thermo 
Fisher Scientific) on $\mathrm{MH}$ agar supplemented with $0.5 \% \mathrm{NaCl}$. The inhibition diameter was recorded after incubation for $48 \mathrm{~h}$ at $22-25^{\circ} \mathrm{C}$. Inhibition diameters were relatively set by Enterobacteriaceae and compared with relevant literature $[19,20]$.

Morphology of the bacteria with emphasis on the cellular components related to motility (flagellum, fimbria, pili) was studied with transmission and scanning electron microscopy. Bacteria were grown for 6 hours in TSB and preserved in 2.5\% glutaraldehyde in phosphate buffer. Bacteria preparations were negatively stained with $4 \%(\mathrm{w} / \mathrm{v})$ uranyl acetate $(\mathrm{pH} 7.2)$ and observed with a JOEL JEM2100 transmission electron microscope (TEM) operated at $80 \mathrm{kV}$. Samples for scanning electron microscope (SEM) were washed with sodium cacodylate buffer, post fixed with $\mathrm{OsO}_{4}$, and dehydrated in an ascending alcohol series, mounted on stubs, and sputter coated with gold-palladium. Bacteria were viewed using a JEOL JSM-6390LV scanning electronic microscope at $20 \mathrm{kV}$. Both TEM and SEM were conducted at the Electron Microscopy Laboratory of the University of Crete.

Hierarchical cluster analysis was conducted on the phenotypic and biochemical data tested including the API 20E, BIOLOG's and catalase reactions, motility, pigment production, and $\beta$-hemolysis (119 characters). Analysis was conducted in IBM SPSS Statistics software using between-groups linkage method with Chi-Square measure.

Nine strains from seabass and one strain from $X$. helleri were subjected to whole genome sequencing. Paired-end sequencing was performed using an Illumina MiSeq platform (Illumina, Inc. San Diego, CA, USA). For the de novo assembly, MaSuRCa genome assembler and SPAdes were used [21]. Quality of the assembled genome sequences was assessed by Benchmarking Universal Single-Copy Orthologs (BUSCO) [22,23]. Gene identification and annotation were done using the NCBI Prokaryotic Genome Annotation Pipeline [24] and RAST [25]. The bacterial genomes were also analyzed in the platform of the Pathosystems Resource Integration Center (PATRIC) [26]. Genomes were deposited to GenBank under the Accession Numbers: NZ_NMUR00000000.1 (NS), NZ_NMUS00000000.1 (PDB), NZ_NPKE00000000.1 (NS 2), NZ_NPKC00000000.1 (NS 6.15.2), NZ_NQMB00000000.1 (NS 13), NZ_NQMC00000000.1 (NS 22), NZ_NNSE00000000.1 (AG 5.28.6), NZ_NNSF00000000.1 (VCK 1), NZ_NPKD00000000.1 (BIOO50A), NZ_SSUX00000000.1 (XU 1).

Multilocus sequence typing (MLST) analysis was conducted based on the Web-based MLST sequence database (https://pubmlst.org/aeromonas/) [27,28]. The allele sequences for the six genetic loci (gyrB, groL, gltA, metG, ppsA, and recA), were retrieved from the ten Aeromonas genomes. The ST profile of each strain was created and compared in the database with other 645 different STs (July 2019). The complete sequences of the six genes were used a) to estimate the genetic distances among seabass strains and with the strains XU 1 and B565 (A. veronii) and b) for phylogenetic analyses (NJ) following concatenation. Analyses were performed in MEGA X [15] under the Tamura-Nei [16] model of evolution. The confidence of tree nodes was tested by the bootstrap analysis with 1000 replicates.

The similarity of the nine genomes isolated from seabass with each other and with other Aeromonas spp. was assessed using Average Nucleotide Identity by Orthology [29] with Ortho-ANI software. Comparisons with other $A$. veronii genomes from different hosts and isolation sources, and the strain XU 1 from X. helleri described here, and the strain A449 of A. salmonicida subsp. salmonicida and the type strain ATCC 7966 of $A$. hydrophila subsp. hydrophila, were also made.

Single nucleotide polymorphisms (SNPs) analysis was done according to [30]. Briefly, SNPs were determined using CSI phylogeny [31,32] available on the CGE (www.genomicepidemiology.org). The paired-end reads of the nine Aeromonas strains were mapped to the reference chromosome of the strain B565. Qualified SNPs were determined when fulfilling the following criteria: (1) A minimum distance of $10 \mathrm{bps}$ between each SNP, (2) a minimum of 10\% of the relative depth at SNP positions, (3) the mapping quality was above 25, (4) the SNP quality was more than 30, and (5) all indels were excluded. The SNPs from each genome were concatenated to a single alignment corresponding to the position of the reference genome. The concatenated sequences were subjected to maximum likelihood analysis using MEGA X. 
The profile of the outer membrane proteins (OMPs) was first studied in the randomly selected strain VCK 1 . The proteome (as predicted by the genomic analysis) of VCK 1 was analyzed in PSORTb v.3.0, a tool for subcellular localization of proteins [33]. The detected OMPs, were further analyzed with Signal IP v.5 in order to detect signal peptides (and cleavage sites) of proteins targeting the outer membrane [34]. TOPCONS2 was used to predict the topology of alpha-helical transmembrane proteins [35] and PRED-TMBB2 to predict the topology of beta-barrel proteins [36]. The set of proteins identified in this way for VCK 1 were also located in the other $A$. veronii strains from seabass, and from strains XU 1 from X. helleri and strain B565 through mapping in Geneious v.9.1.6. Similarity of these proteins was calculated in Geneious using protein distance following alignment of the aminoacidic sequences with the MUSCLE algorithm.

Genomic Islands (GIs) were predicted for the nine isolates from seabass through the online platform Island Viewer v.3 [37] that includes three methods, IslandPick, IslandPath-DIMOB, and SIGI-HMM, for prediction and detection of GIs. Prophage sequences were identified by the PHASTER web server [38]. Virulence genes were detected manually and using the PATRIC annotation platform [26], which combines three databases; PATRIC_VF, VFDB, and VICTORS. Incomplete coding sequences (CDS) located at the edge of contigs were excluded. Special focus was given to the secretion systems, flagellar proteins and toxins, which were studied using alignment with the respective gene clusters identified in the Aeromonas strains of the current study. Alignment was conducted with CLUSTALW and Mauve [39] in Geneious v.9.1.6. Antibiotic Resistance genes were predicted by the Resistance Gene Identifier (RGI) Software of the CARD platform [40].

Adult zebrafish (Danio rerio) (mean weight: $0.3 \mathrm{~g}$ ) were used for assessing the virulence of the nine A. veronii strains from seabass. Fish were acclimatized for at least ten days before handling. Water and room temperature were kept at $25^{\circ} \mathrm{C}$. For each strain, 50 fish were distributed in five 5-L tanks each containing 10 individuals. Five doses $\left(10^{8}-10^{4} \mathrm{cfu} / \mathrm{fish}\right)$ of live bacteria diluted in sterile PBS were injected in the experimental groups while the control group was injected with sterile PBS. The injection (10 $\mu \mathrm{L} /$ fish) was conducted using a Hamilton micro-syringe following anesthesia (MS222). The fish were monitored over a five-day period, dead fish were removed daily, and mortalities were recorded. LD50 value was estimated by the dose-response curve at 24 and $48 \mathrm{~h}$ post injection using Probit analysis in SPSS Statistics. The procedure was performed at the University of Crete which has licensed designated facilities for experimentation with animals (registration number: EL-BIOexp-10) and the protocol was approved by the General Directorate of Regional Agricultural Economy and Veterinary Services of the Region of Crete (License number: 147115/17-07-2017).

\section{Results}

\subsection{Aeromonad Detection and Prevalence}

Aeromonads where detected in fish exhibiting the main clinical signs (loss of appetite, icteric appearance, petechial hemorrhages, etc.) as described previously [9] but also in fish exhibiting only darkening, loss of appetite, and reduced growth (e.g. sampling 4) as well as in younger fish below $50 \mathrm{~g}$. Aeromonads were detected in diseased fish in temperature over $18{ }^{\circ} \mathrm{C}$ (March to December) while outbreaks occurred in summer in water temperature mainly over $23^{\circ} \mathrm{C}$. Over one hundred isolates were identified as Aeromonas spp. with the methodology described before. From the Aeromonas spp. isolated from seabass, 1-7 per sampling (53 in total from seabass) were randomly selected for further characterization and identification to species level together with two isolates from the freshwater fish species (Table 2). Prevalence of aeromonads on diseased fish ranged between $11 \%-75 \%$ (Table 2). Note that in the cases that the bacteria were collected on site by the fish vets, each isolate corresponds to one diseased fish. In these cases, the total number of fish examined is not available and therefore prevalence cannot be estimated. 
Table 2. Number of seabass examined per sampling, Aeromonas spp. detection and prevalence on diseased fish per sampling, number of Aeromonas spp. isolates analyzed in the present study, and the isolates' codes.

\begin{tabular}{|c|c|c|c|c|c|}
\hline Area & \# Sampling & $\begin{array}{c}\text { \# Examined } \\
\text { Fish }\end{array}$ & $\begin{array}{c}\text { Prevalence } \\
\text { in Diseased } \\
\text { Fish }\end{array}$ & $\begin{array}{l}\text { \# Isolates } \\
\text { Analyzed } \\
\text { Herein }\end{array}$ & Isolate Code \\
\hline \multirow[t]{12}{*}{ West Aegean Sea } & 1 & [9] & [9] & 3 & NS, PDA, PDB \\
\hline & $2-3$ & $\geq 7$ & & 3 & NS $2,8,10$ [9] \\
\hline & 4 & 33 & $33 \%(11 / 33)$ & 7 & NS 6 [9] \\
\hline & 5 & $\geq 5$ & & 3 & NS $15-17$ \\
\hline & $6-7$ & $\geq 3$ & & 3 & NS 20-22 \\
\hline & 8 & $\geq 1$ & & 1 & NS 30 \\
\hline & 9 & $\geq 1$ & & 1 & NS 49 \\
\hline & 10 & $\geq 9$ & & 2 & NS $52-58$ \\
\hline & 11 & $\geq 1$ & & 1 & NS 13 \\
\hline & 12 & $\geq 3$ & & 3 & NS 23-25 \\
\hline & 13 & 11 & $73 \%(8 / 11)$ & 2 & NS 29, 31 \\
\hline & 14 & $\geq 10$ & & 2 & NS $32-33$ \\
\hline SUM West & & & & 31 & \\
\hline \multirow[t]{9}{*}{ East Aegean Sea } & 15 & 13 & $15 \%(2 / 13)$ & 3 & AG 2 \\
\hline & 16 & $\geq 1$ & & 1 & VCA \\
\hline & 17 & 4 & $75 \%(3 / 4)$ & 4 & AG 4 \\
\hline & 18 & 26 & $11 \%(3 / 26)$ & 3 & AG 5 \\
\hline & 19 & 5 & $20 \%(1 / 5)$ & 1 & AG 9 \\
\hline & 20 & $\geq 8$ & & 3 & NSK 1-8 \\
\hline & $21-22$ & $\geq 9$ & & 4 & NSK 9-12, VCK \\
\hline & 23 & $\geq 2$ & & 2 & BIOO50A, B \\
\hline & 24 & $\geq 1$ & & 1 & T04-D \\
\hline SUM East & & & & 22 & \\
\hline \multirow[t]{2}{*}{ Other } & 25 & & & 1 & XU 1 \\
\hline & 26 & & & 1 & $\mathrm{Z} 1$ \\
\hline SUM & & & & 55 & \\
\hline
\end{tabular}

\subsection{Molecular Identification and Phylogeny}

For identification to species level, the gyrB gene was amplified and sequenced for all 55 isolates studied. In total four Aeromonas species were identified through BLAST correlation ( $p=99 \%)$, named A. bivalvium, A. media, A. salmonicida and A. veronii. Among them, A. veronii was the most common aeromonad species (50/53 identified isolates) from diseased seabass. Aeromonas media and A. salmonicida, were isolated together from one fish (sampling 15) and A. bivalvium was isolated together with A. veronii from another fish (sampling 17). The isolates $X U 1$ and $Z 1$ were also identified as $A$. veronii through BLAST.

Sequences (1004 bp) from the 53 seabass isolates were included in the phylogenetic analyses. Fifty isolates from seabass and the isolates $\mathrm{XU} 1$ and $\mathrm{Z} 1$ were grouped together and formed a monophyletic clade with $A$. veronii in $\mathrm{NJ}$ analyses based on gyrB sequences (Figure $\mathrm{S} 1$ ). The mean genetic distance between the $A$. veronii isolates from seabass was $0 \%$. The mean genetic distance in the $A$. veronii clade was calculated to $0.015 \%$.

\subsection{Phenotypic and Biochemical Characterization and Identification}

All Aeromonas spp. isolates appeared green on AIA (did not produce acid from xylose) and formed full grown colonies after $48 \mathrm{~h}$ incubation on AIA/TSA. All but two (NS and NS 13) isolates from seabass were motile. The A. veronii isolates form West Aegean Sea (except for NS and NS 13) produced dark brown pigment on TSA and MH agar after 36-48 $\mathrm{h}$ incubation. The $A$. veronii isolates from East Aegean produced a light brown pigment mainly visible on $\mathrm{MH}$ agar. Those were recorded as positive-intermediate (I) for this attribute in the current study. No pigment production was observed in 
broth media. The A. veronii isolates XU 1 and $\mathrm{Z} 1$ from green swordtail and zebrafish respectively, were both motile and non-pigment-producing as well as the type strains LMG 3785 (A. veronii bv. sobria) and LMG 9075 (A. veronii bv. veronii). Results on motility and pigment production are presented in Table 3.

All $A$. veronii isolates from seabass were catalase and oxidase positive, able to ferment $\mathrm{D}$-glucose. All were negative for indole and $\mathrm{H}_{2} \mathrm{~S}$ production, did not hydrolyze urea, and did not ferment amygdalin, arabinose, melibiose, inositol, sorbitol, or rhamnose. All fermented mannitol and sucrose and all but one (BIOO50A) were negative for Ornithine decarboxylase. The majority of western strains were negative for $\beta$-galactosidase while most of the eastern ones were positive. Reactions for ADH and LDC were almost exclusively positive for western strains while for the eastern ones variability was evident. Beta-hemolysis was clearly demonstrated on seabass blood agar for all isolates tested, after incubation for $24 \mathrm{~h}$ at $25^{\circ} \mathrm{C}$. The results reactions of API 20E, catalase, and beta-hemolysis test are presented in Table 3.

Table 3. Results on API 20E reactions, catalase, $\beta$-hemolysis, motility, and pigment production presented as positive/negative reactions for the type strains of $A$. veronii (LMG 3785 and LMG 9075), strains XU 1 and $Z 1$, and as a percentage of positive reactions for each area (West/East) for isolates from seabass.

\begin{tabular}{ccccccc}
\hline Reaction/Strain & $\mathbf{a}$ & $\mathbf{b}$ & $\mathbf{c}$ & $\mathbf{d}$ & West Aegean Sea (\%) & East Aegean Sea (\%) \\
\hline ONPG & + & + & + & ND & $15(4 / 27)$ & $89(16 / 18)$ \\
ADH & + & - & + & ND & 100 & $44(8 / 18)$ \\
LDC & + & + & + & ND & $96(26 / 27)$ & $28(5 / 18)$ \\
ODC & - & + & - & ND & 0 & $6(1 / 18)$ \\
CIT & - & + & + & ND & $85(23 / 27)$ & $67(12 / 18)$ \\
H2S & - & - & - & ND & 0 & 0 \\
URE & - & - & - & ND & 0 & 0 \\
TDA & + & + & + & ND & $96(26 / 27)$ & 100 \\
IND & + & + & + & ND & 0 & 0 \\
VP & + & + & - & ND & $26(7 / 27)$ & $50(9 / 18)$ \\
GEL & + & + & + & ND & $81(22 / 27)$ & 100 \\
GLU & + & + & + & ND & 100 & 100 \\
MAN & + & + & + & ND & 100 & 0 \\
INO & - & - & - & ND & 0 & 0 \\
SOR & - & - & - & ND & 0 & 0 \\
RHA & - & - & - & ND & 0 & 100 \\
SAC & + & + & + & ND & 100 & 0 \\
MEL & - & - & - & ND & 0 & 0 \\
AMY & - & - & - & ND & 0 & 0 \\
ARA & - & - & - & ND & 0 & 100 \\
OX & + & + & + & ND & 100 & $100(19 / 19)$ \\
Catalase & + & + & + & + & $100(31 / 31)$ & $100(18 / 18)$ \\
$\beta$-hemolysis & + & + & + & ND & $100(31 / 31)$ & $100(19 / 19)$ \\
Motility & + & + & + & + & $94(29 / 31)$ & $100(19 / 19) *$ \\
Pigment production & - & - & - & - & $94(29 / 31)$ & $100(15 / 15)$ \\
O/129 & + & + & + & + & $100(22 / 22)$ & ( \\
\hline
\end{tabular}

a: LMG 3785 A. veronii bv. sobria, b: LMG 9075 A. veronii bv. veronii, c: XU 1, d: Z 1, (+): Positive reaction, $(-)$ : Negative reaction, ND: Not done, ${ }^{*}$ Intermediate pigment production.

Identification in BIOLOG's database (Microlog 5.2) identified the seabass isolates as A. hydrophila-like, DNA group 2, or in few occasions, as A. sobria (e.g., PDB). All grew in pH 6 and $1 \% \mathrm{NaCl}$ but growth in $\mathrm{pH} 5$ was variable and only few were able to grow in salinity $\geq 4 \% \mathrm{NaCl}$. All the western isolates and none but two (T04-D and AG-5.34.6) eastern ones fermented trehalose. Additionally, none but three (AG-5.34.6, NS 31.2.1, and NS 33.1) were able to produce acid from $\mathrm{D}$-arabitol. Western/eastern isolates differed also in the metabolism of $\beta$-Methyl-D-Glucoside (-/+) and D-Gluconic acid (+/-). Results of BIOLOG's reactions are presented in Table S1. Intermediate reactions were not included in the percentage calculation but were assigned as intermediate character in cluster analysis. All seabass isolates were identified to genus level as Aeromonas spp. considering the commercial kits used for identification. 


\subsubsection{Electron Microscopy}

Both TEM and SEM analysis confirmed that the non-motile strains lack flagella (Figure 1). On the contrary, motile strains possess a single polar flagellum. Lateral flagella were not observed in the examined samples. A fuzzy coat was observed around the cell of the motile strains both in TEM and SEM samples, a structure resembling bacterial capsule.

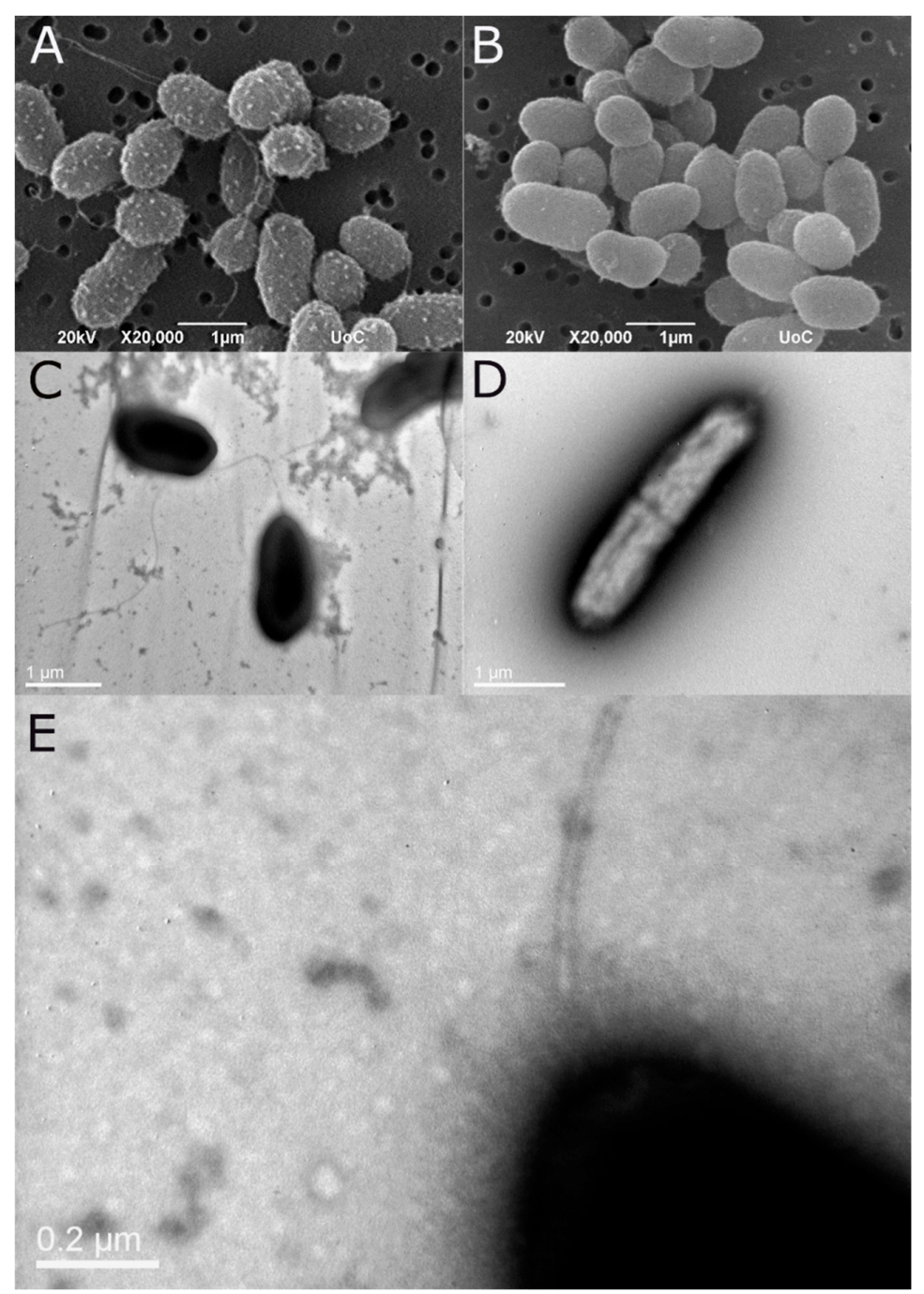

Figure 1. SEM micrograph of the motile strain PDB (A) and the non-motile NS (B). The same strains as shown in TEM following negative stain $((\mathbf{C}, \mathbf{D})$, respectively). The presence of a polar flagellum is evident only in the motile strain (PDB). Higher magnification of the polar flagellum of strain PDB (E). Note the fuzzy coat of the cell possibly related to capsule.

\subsubsection{Cluster Analysis}

Five main groups were recognized in hierarchical cluster analysis (Figure 2): One consisting of the motile-pigment producing, West Aegean Sea isolates from Argolikos and Saronikos Bay, one consisting of the motile-(I)-pigment producing, East Aegean Sea isolates from Agathonisi Isl., Kalymnos Isl., and Turkey (Güllück), one represented by strain XU 1 from X. helleri alone, one consisting of the non-motile, non-pigment producing NS and NS 13 from West Aegean Sea grouped with the type strain of A. veronii bv. sobria (LMG 3785), and finally one represented by the most diverged among seabass isolates eastern strain AG 5.34.6 (sampling 18) which is motile-(I)-pigment producing. The type strain of A. veronii bv. veronii (LMG 9075) served as an outgroup in the present analysis. No internal group patterns were detected according to e.g., date of isolation or fish farm. When motility and pigment production 
were excluded from the dataset (dendrogram not presented), the group of NS, NS 13, and LMG 3785 (as well as the cluster of XU 1), were all clustered in the broader West Aegean Sea cluster representing the West/East geographic origin pattern for seabass isolates. Finally, the strains not included in the present analysis (NS 33.1, NS 49, NS 52, NS 58, T04-D, and Z 1) because of incomplete data on their biochemical properties, were analyzed separately including data of BIOLOG, catalase, motility, and pigment production. The strain Z 1 was grouped together with AG 5.34.6 and the rest with the West Aegean Sea group.

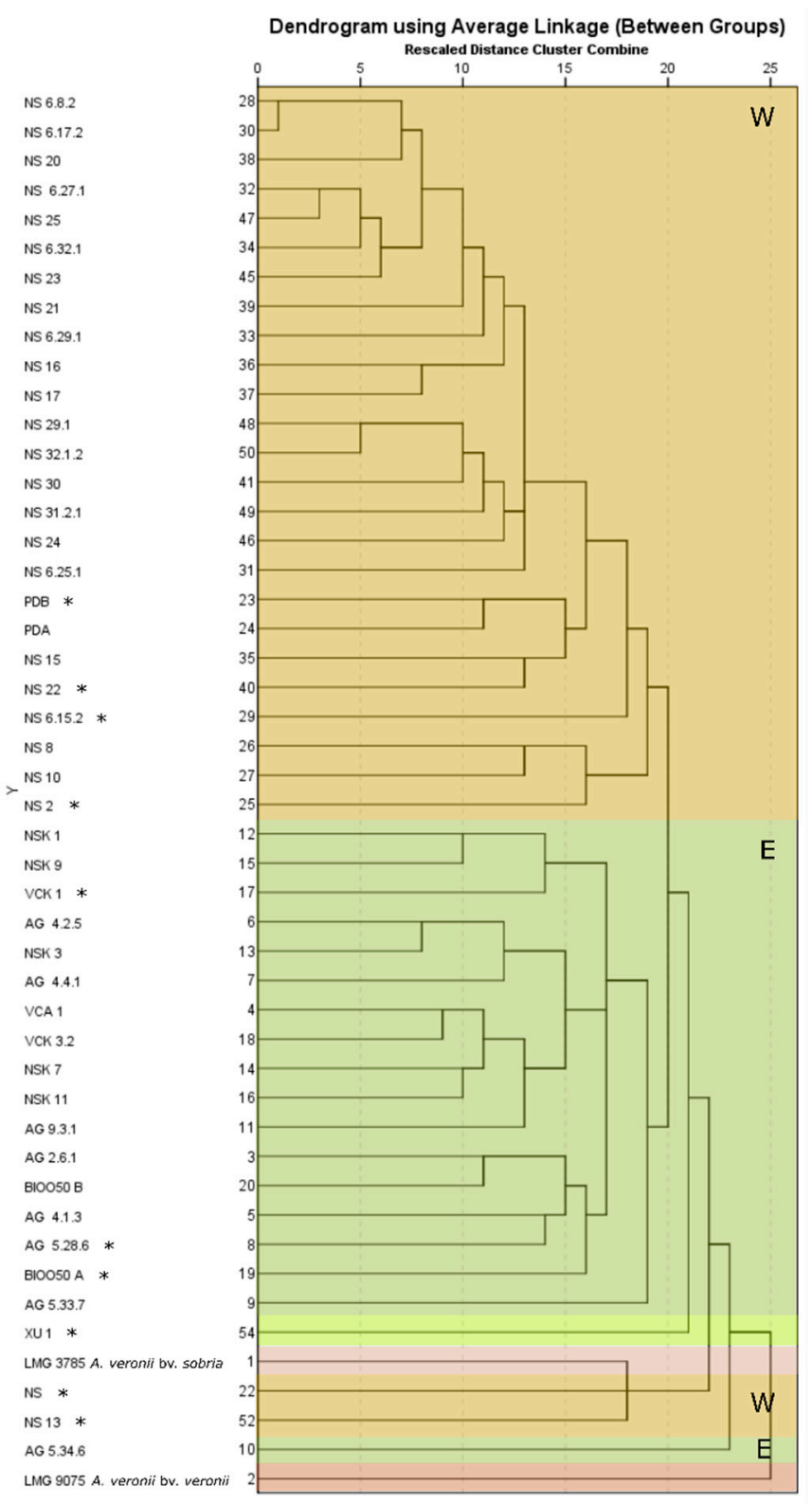

Figure 2. Dendrogram produced by Hierarchical cluster analysis on $45 \mathrm{~A}$. veronii isolates from diseased seabass, the strains XU 1 and the type strains of A. veronii bv. sobria (LMG 3785) and A. veronii bv. veronii (LMG 9075). Characters analyzed included the API 20E, BIOLOG's and catalase reactions, motility, pigment production, and $\beta$-hemolysis (119 characters). Western isolates are noted with $\mathrm{W}$ and eastern ones with E. Asterisk $\left(^{*}\right)$ indicates the sequenced strains' genomes.

\subsection{Antibiotic Susceptibility}

Susceptibility test for the vibriostatic agent O/129, showed an inhibition zone (West Aegean isolates) or faint inhibition zone (East Aegean isolates) ranging between 7-9 $\mathrm{mm}$ for the majority of 
tested isolates. Nevertheless, growth was also evident in this area, or inhibition was not present after $48 \mathrm{~h}$ of incubation and thus, all isolates were finally assigned as resistant (Table 3) including the strains NS and PDB that were initially reported as sensitive [9]. The type strains LMG 3785 and LMG 9075 as well as the isolates XU 1 and $\mathrm{Z} 1$ were also resistant to the vibriostatic agent $\mathrm{O} / 129$ (Table 3). All isolates were resistant to ampicillin. All seabass isolates were susceptible to oxytetracycline tetracycline, oxolinic acid, and florfenicol. All but one of them (NS 6.25.1) were susceptible to flumequine and all but two (NS 6.25.1 and NS 6.27.1) to Trimethoprim/sulfamethoxazole. Isolates XU 1 and Z 1 were resistant to oxytetracycline, tetracycline, and oxolinic acid. The $\mathrm{Z} 1$ was also resistant to flumequine. Susceptibility to antibiotics agents is presented as mean inhibition diameter $(\mathrm{mm})$ for each locality and as inhibition diameter for distinct strains (Table 4). Extreme values are presented separately.

Table 4. Antibiotic susceptibility profiles for Aeromonas spp. isolates presented as mean inhibition diameter $(\mathrm{mm})$ for the isolates of each locality and as inhibition diameter for unique ones. Outliers are presented below the mean diameter.

\begin{tabular}{|c|c|c|c|c|c|c|c|c|c|c|}
\hline \multirow{2}{*}{$\begin{array}{c}\# \\
\text { Sampling }\end{array}$} & \multirow[b]{2}{*}{ Area } & \multirow[b]{2}{*}{ Locality } & \multirow{2}{*}{$\begin{array}{c}\text { \# Isolates/ } \\
\text { Locality }\end{array}$} & \multicolumn{7}{|c|}{ Inhibition Diameter } \\
\hline & & & & $\begin{array}{c}\text { OT } \\
(30 \mu \mathrm{g})\end{array}$ & $\begin{array}{c}\text { TE } \\
(30 \mu \mathrm{g})\end{array}$ & $\begin{array}{c}\text { UB } \\
(30 \mu \mathrm{g})\end{array}$ & $\begin{array}{c}\text { SXT } \\
(25 \mu \mathrm{g})\end{array}$ & $\begin{array}{c}\mathrm{OA} \\
(2 \mu \mathrm{g})\end{array}$ & $\begin{array}{c}\text { FFC } \\
(30 \mu \mathrm{g})\end{array}$ & $\begin{array}{c}\text { AMP } \\
(10 \mu \mathrm{g})\end{array}$ \\
\hline $1-10$ & $\mathrm{~W}$ & Argolikos Bay & $\begin{array}{c}22 \\
\text { (NS 6.25.1) } \\
\text { (NS 6.27.1) }\end{array}$ & $37 \pm 3$ & $36 \pm 4$ & $\begin{array}{c}35 \pm 5 \\
19\end{array}$ & $\begin{array}{c}28 \pm 7 \\
11 \\
6\end{array}$ & $33 \pm 3$ & $39 \pm 3$ & 0 \\
\hline 11 & W & Argolikos Bay & 1 (NS 13) & 42 & 42 & 44 & 30 & 38 & 42 & \\
\hline $12-14$ & W & Saronikos Bay & 7 & $37 \pm 2$ & $37 \pm 2$ & $35 \pm 3$ & $28 \pm 3$ & $32 \pm 3$ & $39 \pm 2$ & 0 \\
\hline $15-19$ & $\mathrm{E}$ & Agathonisi Isl. & 9 & $37 \pm 1$ & $36 \pm 2$ & $37 \pm 1$ & $22 \pm 2$ & $31 \pm 1$ & $40 \pm 1$ & 0 \\
\hline $20-22$ & E & Kalymnos Isl. & 7 & $35 \pm 1$ & $36 \pm 2$ & $36 \pm 1$ & $20 \pm 3$ & $30 \pm 2$ & $38 \pm 2$ & 0 \\
\hline 23 & $\mathrm{E}$ & Güllück & 2 & $35 \pm 4$ & $35 \pm 1$ & $35 \pm 5$ & $21 \pm 1$ & $34 \pm 0$ & $41 \pm 1$ & 0 \\
\hline 24 & $\mathrm{E}$ & Bodrum & 1 (T04-D) & 30 & 30 & 33 & 22 & 29 & 37 & 0 \\
\hline 25 & other & N/E Greece & $1(\mathrm{Z} 1)$ & 7 & 11 & 0 & 24 & 0 & 34 & 0 \\
\hline 26 & other & Crete & $1(\mathrm{XU} 1)$ & 7 & 12 & 28 & 24 & 15 & 40 & 0 \\
\hline
\end{tabular}

W: West Aegean Sea, E: East Aegean Sea.

\subsection{Whole Genome Sequencing}

Whole genome sequencing was performed on ten strains selected on the basis of geographic origin, fish farm and time of isolation, phenotypic characteristics, and host organism (Table 5). An overview of their genome features and Accession Numbers in NCBI GenBank are presented in Table S2. The de novo assembly resulted in 92 to 172 contigs with average length $>27.5 \mathrm{~kb}$ and $\mathrm{N}_{50}$ values from $61.224,00$ to $85.872,00$. Full assembly data can be retrieved from Table S3. Quality data regarding the assembly following BUSCO analysis are shown in Table S4.

Table 5. Characteristics of the selected for whole genome sequencing strains.

\begin{tabular}{ccccccc}
\hline Strain & Area & Locality (Fish Farm) & Host & Collection Date & Motility & Pigment \\
\hline NS & W & Argolikos Bay (1-2) & D. labrax & $2009[9]$ & - & - \\
PDB & W & Argolikos Bay (1-2) & D. labrax & $2009[9]$ & + & + \\
NS 2 & W & Argolikos Bay (1-2) & D. labrax & 2015 & + & + \\
NS 6.15.2 & W & Argolikos Bay (1-2) & D. labrax & 2015 & + & + \\
NS 13 & W & Argolikos Bay (3) & D. labrax & 2015 & - & - \\
NS 22 & W & Argolikos Bay (1-2) & D. labrax & 2016 & + & + \\
AG 5.28.6 & E & Agathonisi Isl. (5) & D. labrax & 2015 & + & I \\
VCK 1 & E & Kalymnos Isl. (6) & D. labrax & 2015 & + & I \\
BIOO50A & E & Güllück (7) & D. labrax & 2010 & + & I \\
XU 1 & other & N/E Greece (9) & X. helleri & 2015 & + & - \\
\hline
\end{tabular}

W: West Aegean Sea, E: East Aegean Sea, (+): Positive reaction, (-): Negative reaction, I: Intermediate pigment production. 


\subsubsection{Multilocus Sequence Typing (MLST)}

Comparison of the alleles of the nine Aeromonas strains from seabass in the PubMLST database, showed that all belonged to ST 23 (allele type for gyrB: 25, groL: 24, gltA: 25, metG: 24, ppsA: 22, and recA: 24). This profile corresponded to the A. veronii strains Ae4 and Ae59, both isolated in 1999 from diseased European seabass from Italy. The seabass strains showed $100 \%$ similarity $(0 \%$ genetic distance) in the complete gene sequences of $g l t \mathrm{~A}, g r o \mathrm{~L}, g y r \mathrm{~B}, m e t \mathrm{G}$, and $r e c \mathrm{~A}$ while for $p p s \mathrm{~A}$ distance was calculated to $0.001 \%$. Mean genetic distance in the A. veronii clade (seabass-XU 1-B565) was $0.006 \%$ for $g l t \mathrm{~A}, 0.011 \%$ for $g r o \mathrm{~L}, 0.006 \%$ for $g y r \mathrm{~B}, 0.011 \%$ for $m e t \mathrm{G}, 0.019 \%$ for $p p s \mathrm{~A}$, and $0.012 \%$ for $r e c \mathrm{~A}$. In the $\mathrm{NJ}$ analyses, the nine seabass strains and XU 1 grouped together and formed a monophyletic clade with the A. veronii strain B565 (Figure 3). The strain XU 1 did not belong to any ST in the database.

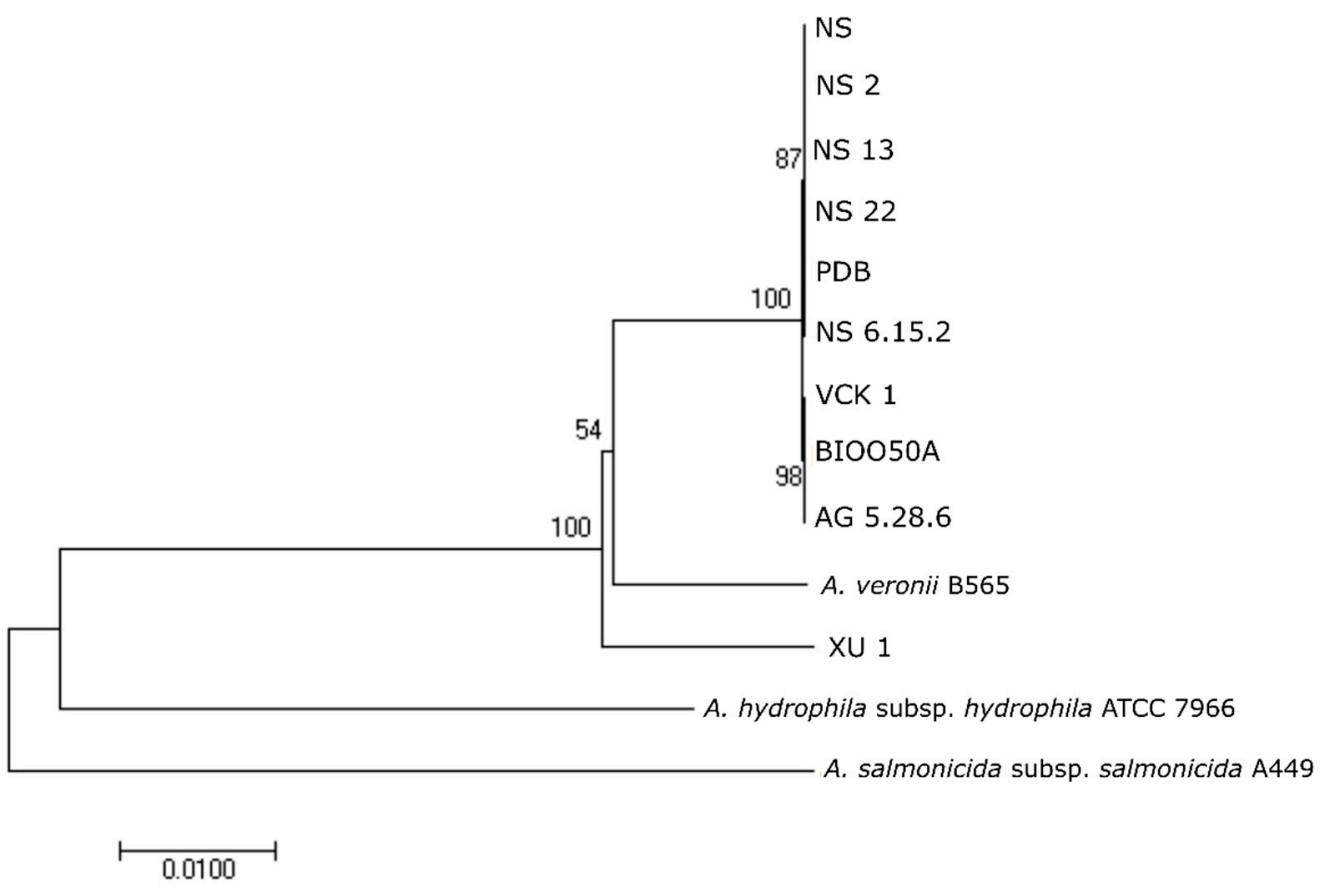

Figure 3. Phylogenetic relationships between seabass strains based on neighbor joining (NJ)-multilocus sequence typing (MLST) analysis on concatenated complete sequences of $g y r \mathrm{~B}$, groL, gltA, met $\mathrm{G}, p p s \mathrm{~A}$, and recA genes. Numbers on branches indicate the bootstrap values.

\subsubsection{Whole Genome Comparison}

The nine seabass isolates were found closely related with calculated Ortho-ANI values ranging between $99.65 \%-99.99 \%$. Isolates formed two groups (West/East Aegean Sea respectively) with internal Ortho-ANI similarity $\geq 99.97 \%$ (Figure $4 \mathrm{~A}$ ). Mean ANI values of strains NS and VCK 1 (randomly selected representatives for each geographic area) with 22 other $A$. veronii genomes were $96 \% \pm 0.5 \%$ for both. Further comparisons with other Aeromonas spp. are presented in Figure 4B. All estimated ANI values are presented in Table S5. 
A

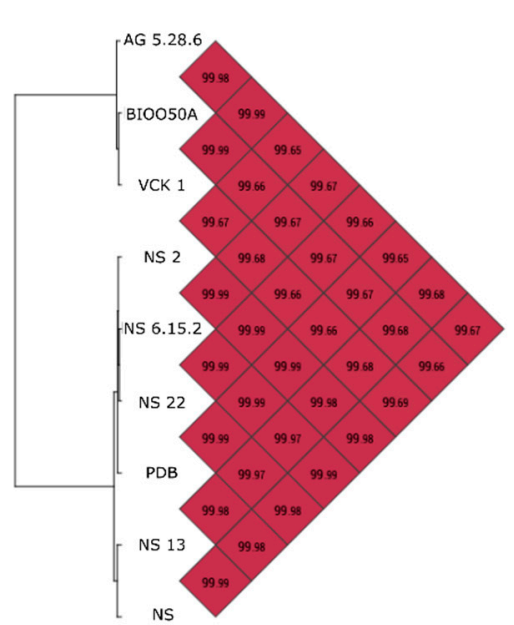

B

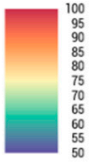

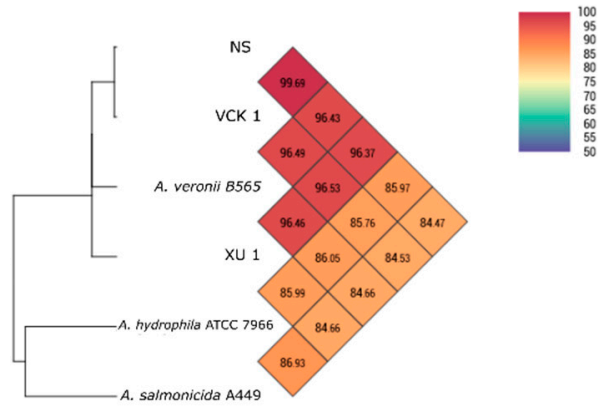

Figure 4. (A) Genome similarity Heatmap with OrthoANI values for the nine seabass strains sequenced. (B) Genome similarity Heatmap with OrthoANI values for the randomly selected representatives of West/East strains (NS, VCK 1) compared with other genomes of Aeromonas spp.

The results of the SNPs analysis also grouped the isolates into two groups which represent their geographic origin (Figure 5). The average SNP difference among the eastern isolates was between 7-15 while the average SNP difference among the western isolates was between 6-168 (Table 6). Difference among western-eastern isolates was greater than 3700 .

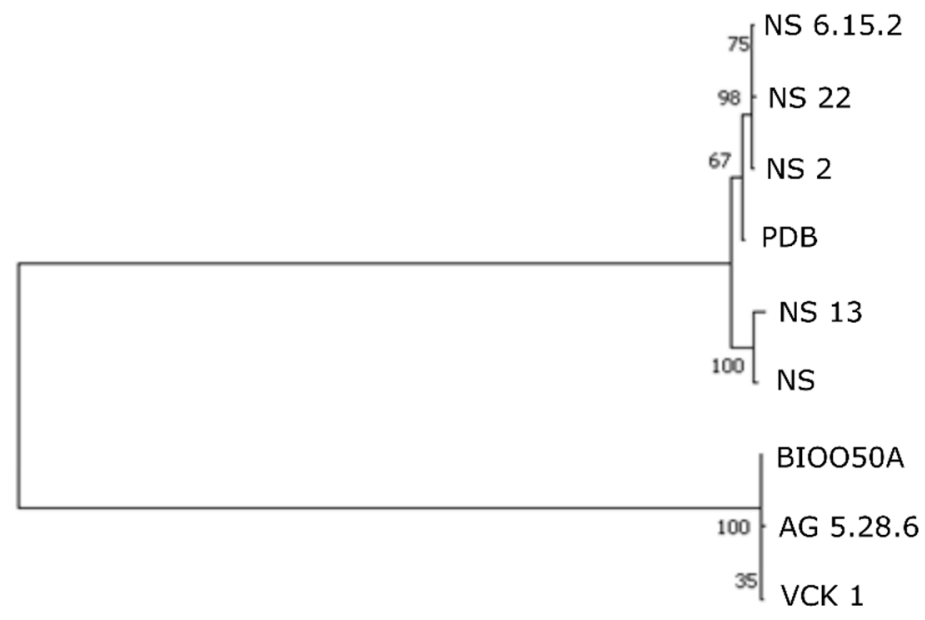

0.10

Figure 5. The evolutionary history of the nine strains from seabass inferred by maximum likelihood analysis on single nucleotide polymorphisms (SNPs). 
Table 6. Single nucleotide polymorphisms (SNPs) matrix of the nine sequenced $A$. veronii isolates.

\begin{tabular}{|c|c|c|c|c|c|c|c|c|c|}
\hline & NS & PDB & NS 2 & NS 6.15 .2 & NS 13 & NS 22 & AG 5.28.6 & VCK 1 & BIOO50A \\
\hline NS & & & & & & & & & \\
\hline PDB & 119 & & & & & & & & \\
\hline NS 2 & 146 & 49 & & & & & & & \\
\hline NS 6.15 .2 & 137 & 40 & 11 & & & & & & \\
\hline NS 13 & 40 & 139 & 168 & 159 & & & & & \\
\hline NS 22 & 139 & 40 & 15 & 6 & 159 & & & & \\
\hline AG 5.28.6 & 3795 & 3836 & 3863 & 3854 & 3817 & 3856 & & & \\
\hline VCK 1 & 3797 & 3838 & 3856 & 3856 & 3819 & 3858 & 18 & & \\
\hline BIOO50A & 3794 & 3835 & 3862 & 3853 & 3816 & 3855 & 15 & 7 & \\
\hline
\end{tabular}

\subsection{Outer Membrane Proteins' Profile}

In total 65 proteins were detected with PSORTb for outer membrane localization (score $\geq 8$ ). Amongst them, 43 were predicted to have transmembrane (TM) beta-strands through PRED-TMBB2 and were further compared (Table S6). Eighteen porins were detected belonging to OmpA family (5), general bacterial porins (GBP) family (3), sugar porin family (2), outer membrane protein insertion porin (OmpIP/Omp85) family (2), FadL outer membrane protein (FadL) family (2), the outer membrane porins $\mathrm{D}(\mathrm{OprD})$ and $\mathrm{OmpW}$, the poly-beta-1,6 N-acetyl-D-glucosamine export porin PgaA, and one hypothetical protein belonging to Nucleoside-specific Channel forming outer membrane porin (Tsx) family. Other outer membrane components detected include proteins of the outer membrane receptor (TonB) and outer membrane factor (TolC) families, the ShlB protein member of two-partner secretion (TPS) family, involved in the activation/secretion of hemolysin and the lipopolysaccharide assembly protein LptD. Secretins and filamentous hemagglutinin proteins were also detected.

The OMP profiles of the nine strains were very similar. All proteins retrieved from VCK 1 were detected in the other seabass genomes, and in most cases protein similarity was found $\geq 99 \%$. In most cases the small differences found in the protein sequence reflected the West/East geographic origin of the seabass strains. Maltoporin LamB was distinct (53\% similarity) among the West/East Aegean Sea isolates. The MshL protein sequence of strains PDB, NS 22, and AG 5.28.6 had stop codons, the BamA was different by 16-17 aa between West/East Aegean Sea isolates while the more recent western ones differed by 1 aa from the older ones. The transporter protein (transporter CDS-1) differed by 2 aa among the western non-motile, non-pigment-producing strains (NS, NS 13), the western motile, pigment producing (PDB, NS 2, NS 22, NS 6.15.2), and the eastern motile, I-pigment producing (VCK 1 , BIOO50A, AG 5.28.6) strains.

The S-layer protein gene was found incomplete on strains NS, NS 2, PDB, VCK 1, and AG 5.28.6. Furthermore, S-layer protein sequences of strains BIOO50A (East) and NS 13, NS 22, and NS 6.15.2 (West) differed in length by 87 aa. Finally, the filamentous hemagglutinin N-terminal domain-containing protein was found to be frame-shifted including stop codons in strains PDB, VCK 1, and AG 5.28.6. The rest of the West/East Aegean Sea strains had identical protein sequences. Three tandem homologues of OmpA porin family were found: Porin OmpA CDS-2 (1020 bp): Porin OmpA CDS-1 (999 bp), and hypothetical protein CDS-8 (1038 bp).

Comparing with other strains, the aminoacidic sequences from seabass were generally more similar to the ones of strain B565. In a few cases such as TonB-dependent hemoglobin/transferrin/lactoferrin family receptor and the LPS-assembly protein LptD the opposite was observed. Moreover, the PgaA protein, ShlB/FhaC/HecB family hemolysin secretion/activation protein, S-layer family protein, and filamentous hemagglutinin were not detected neither in B565 nor XU 1 with the methodology followed here. Finally, the maltoporin LamB was identical among western isolates and strain B565. 


\subsection{Virulence}

\subsubsection{Genomic Islands}

All nine genomes contained GIs, with average 24 GIs per genome. From the GIs detected by the tools used, the ones greater than $9.5 \mathrm{kbp}$ were chosen. The average length was 20,731 bp and the coverage of the genome approximately $10.4 \%$ (Table 7 ). The percentage of the hypothetical proteins within the GIs was the same with the genomes. Approximately $32 \%$ of the GIs contained virulence factors. As for the virulence genes in the GIs, the hemolysin D, RTX toxin, Hcp1, iron acquisition, type III secretion system, and flagellar proteins were detected. In addition, PDB and NS22 GIs contained a resistance-nodulation-cell division (RND) antibiotic efflux pump gene (adeF). According to the analysis of PHASTER the genomes of the nine strains had no intact prophage regions (PRs), but the number of the incomplete (completeness score less than 70) and questionable (completeness score 70-90) prophages varied from one to four (Table 7).

Table 7. Main features of the genomic islands and prophage regions of the nine seabass strains.

\begin{tabular}{|c|c|c|c|c|c|c|c|c|c|}
\hline Strain & $\begin{array}{l}\text { Num. of } \\
\text { GIs } \\
(>9.5 \mathrm{kbp})\end{array}$ & $\begin{array}{l}\text { Num. of } \\
\text { Pathogenicity } \\
\text { Islands }\end{array}$ & $\begin{array}{c}\text { Mean } \\
\text { Length } \\
\text { (bp) }\end{array}$ & $\begin{array}{c}\text { Total Size } \\
\text { (bp) }\end{array}$ & $\begin{array}{c}\text { Total Size } \\
\text { of GIs/ } \\
\text { Genome } \\
\text { Size }\end{array}$ & $\begin{array}{l}\text { Num. } \\
\text { HP/CDS } \\
\text { in GIs }\end{array}$ & $\begin{array}{c}\text { Num. of } \\
\text { Incomplete } \\
\text { PRs }\end{array}$ & $\begin{array}{c}\text { Num. of } \\
\text { Questionable } \\
\text { PRs }\end{array}$ & $\begin{array}{c}\text { Mean } \\
\text { Length of } \\
\text { PRs (bp) }\end{array}$ \\
\hline NS & 22 & 10 & $21,734.45$ & 478,158 & 0.10 & 0.44 & 1 & 0 & 5800 \\
\hline PDB & 27 & 11 & $19,939.22$ & 538,359 & 0.11 & 0.46 & 3 & 1 & 11,850 \\
\hline NS 2 & 22 & 7 & $22,938.23$ & 504,641 & 0.11 & 0.54 & 4 & 1 & 7500 \\
\hline NS 6.15 .2 & 23 & 7 & $19,148.00$ & 440,404 & 0.09 & 0.51 & 1 & 0 & 34,100 \\
\hline NS 13 & 29 & 12 & $21,208.76$ & 615,054 & 0.13 & 0.51 & 2 & 0 & 5700 \\
\hline NS 22 & 29 & 10 & $20,771.86$ & 602,384 & 0.13 & 0.53 & 1 & 1 & 8900 \\
\hline AG 5.28.6 & 21 & 5 & $20,606.10$ & 432,728 & 0.09 & 0.49 & 4 & 0 & 12,825 \\
\hline VCK 1 & 19 & 5 & $21,704.58$ & 412,387 & 0.09 & 0.53 & 2 & 0 & 6100 \\
\hline BIOO50 A & 19 & 6 & $18,523.74$ & 351,951 & 0.08 & 0.55 & 3 & 1 & 11,850 \\
\hline
\end{tabular}

GIs: Genomic islands, HP: Hypothetical proteins, PRs: Prophage regions.

\subsubsection{Virulence Genes}

The genes of virulence factors (secretion systems, flagella, toxins, etc.) that were detected manually and through PATRIC are listed in Table S7. Gene clusters of type II and type III secretion systems were present in all seabass strains (Table 8). Examining the type III secretion system, most of the genes composing the system's cluster were found, and syntenies were conserved among the nine strains and other species of gram-negative bacteria according to the RAST annotation. Both apparatus' proteins and effectors were included. The type VI secretion system gene cluster (about $21 \mathrm{kbp}$ ) was detected only on the eastern strains.

Table 8. Prominent virulence factors' gene clusters detected in seabass strains.

\begin{tabular}{cccc}
\hline Virulence Factors & Gene Cluster & West Aegean & East Aegean \\
\hline Type II secretion system & Cluster 1 & + & + \\
Type III secretion system & Cluster 1 & + & + \\
& Cluster 2 & + & + \\
Type VI secretion system & Cluster 3 & + & + \\
Flagellar proteins & Cluster 1 & - & + \\
& Cluster 1 & + & $+{ }^{\mathrm{a}}$ \\
& Cluster 2 & + & $+{ }^{\mathrm{b}}$ \\
& Cluster 3 & + & + \\
& Cluster 4 & + & + \\
\hline
\end{tabular}

(+): detected, (-): not detected, a: Incomplete sequence in VCK 1, b: Incomplete sequence in B, IOO50A, c: Incomplete sequence in NS and NS 13. 
Great variability was found between strains in the exotoxins group (Table 9). The secreted proteins existed in multiple CDS in the genomes (Table S7), identical or not. The Hcp1, which is secreted by the type VI secretion system, was present in most of the strains. In BIOO50A was found at the end of the contig. The membrane fusion protein hemolysin $\mathrm{D}(h l y D)$ (type I secretion system), had seven CDS common between the seabass strains. The aerolysin family beta-barrel pore-forming toxin was complete only in the eastern strains, while in the western ones was detected fragmented by an integrase. Other virulence factors detected were the type IV pili twitching motility protein PilT, the MSHA biogenesis proteins, the TonB-ExbB-ExbD system, and iron acquisition proteins. The RGI predicted four antibiotic resistance genes, common in all the nine strains, the OXA beta-lactamase (OXA-12), the CphA beta-lactamase (cphA3), and two resistance-nodulation-cell division (RND) antibiotic efflux pump genes (adeF).

Table 9. Secreted proteins/exotoxins detected in seabass strains.

\begin{tabular}{cccc}
\hline Virulence Factors & West Aegean & East Aegean & \% Identity \\
\hline Hcp1 & + & $+{ }^{\mathrm{a}}$ & $>90$ \\
hemolysin secretion protein D $(1.419 \mathrm{bp})$ & + & + & $>99$ \\
Hemolysin III & + & + & $>99$ \\
Aerolysin family beta-barrel pore-forming & $-\mathrm{b}$ & + & $<60$ \\
Hemagglutinin & + & + & $>99$ \\
RTX toxin & + & + & $>99$ \\
\hline
\end{tabular}

(+): detected, (-): not detected, a: Incomplete sequence, b: Fragmented sequence.

The A. veronii genomes had five gene clusters containing flagellar genes (Table 8 and Table S7). Seven more genes related to flagellum were detected scattered in other areas of the genome. Six of them encoded components of the flagellar motor $(\operatorname{mot} A, \operatorname{mot} B, \operatorname{mot} X, \operatorname{mot} Y, \operatorname{pom} A$, and $\operatorname{pom} B)$ and the last the $f l g T$, whose protein is a component of $\mathrm{H}$-ring (a structure required for the proper assembly of Pom $\mathrm{AB}$ stator complex). Approximately 105 genes were detected involved in the formation of the flagellum. Following alignment of the respected loci and genes of the motile strain PDB and the non-motile NS, differences were identified in four genes out of the 105. These were the $f \lg G$, flgT, fliI, and fliS.

\subsection{In Vivo Virulence Test}

LD50 was calculated for both a 24 and $48 \mathrm{~h}$ period. The LD50-24 ranged from $4.2 \times 10^{5}$ to $2.4 \times 10^{6}$ and LD50-48 ranged from $3.3 \times 10^{5}$ to $1.4 \times 10^{6} \mathrm{cfu} / \mathrm{fish}$ (Table 10). After probit analysis and comparisons through the relative median potency table, the LD50 values were not found significantly different. There was a tendency for the non-motile western strains NS and NS13 strains to have the lowest LD50 values.

Table 10. Probit analysis LD50 (cfu/fish) of the nine seabass strains at 24 and $48 \mathrm{~h}$.

\begin{tabular}{ccccc}
\hline Strain & LD50 (24 h) & $\mathbf{9 5 \% ~ C o n f i d e n c e ~ I n t e r v a l ~}$ & LD50 (48 h) & $\mathbf{9 5 \% ~ C o n f i d e n c e ~ I n t e r v a l ~}$ \\
\hline NS & $4.2 \times 10^{5}$ & $\left(2.6 \times 10^{4}, 4.5 \times 10^{6}\right)$ & $3.3 \times 10^{5}$ & $\left(1.4 \times 10^{4}, 4.3 \times 10^{6}\right)$ \\
PDB & $2.4 \times 10^{6}$ & $\left(1.2 \times 10^{5}, 2.3 \times 10^{7}\right)$ & $1.4 \times 10^{6}$ & $\left(4 \times 10^{4}, 1.7 \times 10^{7}\right)$ \\
NS 2 & $1.6 \times 10^{6}$ & $\left(1.3 \times 10^{5}, 1.3 \times 10^{7}\right)$ & $1.1 \times 10^{6}$ & $\left(5.8 \times 10^{4}, 10^{7}\right)$ \\
NS 6.15.2 & $1.1 \times 10^{6}$ & $\left(8.6 \times 10^{4}, 1.1 \times 10^{7}\right)$ & $5.4 \times 10^{5}$ & $\left(8.5 \times 10^{3}, 7.2 \times 10^{6}\right)$ \\
NS 13 & $5.4 \times 10^{5}$ & $\left(3.6 \times 10^{4}, 6.6 \times 10^{6}\right)$ & $3.3 \times 10^{5}$ & $\left(1.4 \times 10^{4}, 4.9 \times 10^{7}\right)$ \\
NS 22 & $10^{6}$ & $\left(7.3 \times 10^{4}, 10^{7}\right)$ & $8.4 \times 10^{5}$ & $\left(3.9 \times 10^{4}, 10^{7}\right)$ \\
AG 5.28.6 & $7.1 \times 10^{5}$ & $\left(1.1 \times 10^{4}, 10^{7}\right)$ & $6.9 \times 10^{5}$ & $\left(7.1 \times 10^{3}, 10^{7}\right)$ \\
VCK 1 & $7.9 \times 10^{5}$ & $\left(5.1 \times 10^{4}, 9.6 \times 10^{6}\right)$ & $7.8 \times 10^{5}$ & $\left(3.6 \times 10^{4}, 1.1 \times 10^{7}\right)$ \\
BIOO50 A & $1.3 \times 10^{6}$ & $\left(5.8 \times 10^{4}, 1.2 \times 10^{7}\right)$ & $10^{6}$ & $\left(3.7 \times 10^{4}, 1.1 \times 10^{7}\right)$ \\
\hline
\end{tabular}




\section{Discussion}

Aeromonas veronii was isolated from diseased European seabass farmed in seven localities in both West and East Aegean Sea. The species was the most prevalent in all incidents of Aeromonas-suspected infections with key clinical signs lethargy, icteric appearance and petechial hemorrhages externally, splenomegaly and nodules on spleen and kidney internally, as initially described [9]. To our knowledge this is the first study after the description of the disease that directly correlates this pathology of seabass with $A$. veronii in a large geographic area. The study aimed to record and describe the variability of the pathogen in the affected areas and set the basis for the disease's management in the future. Comparative analysis was conducted on different features of the pathogen.

Aeromonas veronii was the most prevalent species in all incidents of Aeromonas infections in seabass in both sides of the Aegean Sea (West/East). In the case of fish farm 1 (West) where the disease was initially described [9] we can now talk for an established problem as long as A. veronii was isolated from diseased fish almost all year round (March-December) excluding the winter months (temperature $<18^{\circ} \mathrm{C}$ ), over the past ten years. Regarding the West Aegean Sea, while initially the disease was reported to affect only two neighboring fish farms in Argolikos Bay, it has now affected one more farm in the same area but more importantly it has geographically expanded to the neighboring Saronikos Bay where aquaculture activity is very intensive.

In the East Aegean Sea, the situation appeared less persistent. Reports for aeromonad outbreaks were not constant in time. Outbreaks also occurred during the summer months. Fish exhibiting the typical clinical signs of $A$. veronii disease are still present in the field in summer months (personal communications with fish farmers) but are not considered a threat for the moment because impacts are much lower than those recorded in the West Aegean Sea. Nevertheless, a recent outbreak in Bodrum (sampling 24) and the similarities of strain T04-D with the rest of eastern isolates should be considered when discussing the disease's occurrence in East Aegean Sea. In any case, the ability to cause hemolysis in seabass blood agar was observed in all tested isolates, an attribute related to the hepatic jaundice and the icteric appearance of the diseased fish in the field but also to the in vivo hemolysis observed in seabass challenged with strains NS and PDB [9]. Pathogenicity tests in zebrafish showed similar virulence ability for all the strains. However, it should be noted that virulence in seabass is much higher following intraperitoneal injection with doses as low as $10^{4} \mathrm{cfu}$ per fish resulting in $100 \%$ mortality within $48 \mathrm{~h}$. This together with the fact that other fish species cultured in adjacent cages are not affected during disease outbreaks suggests either an adaptation of the pathogen to this host, or an increase sensitivity of seabass to $A$. veronii. This should be further investigated in future studies.

The same species (A. veronii bv. sobria) has been reported in diseased seabass and seabream in Italy [27], and from diseased seabass in one more case in the Black Sea [41]. In the latter, the bacterium was reported as the most prevalent species in diseased seabass, isolated alone, or in mixed-infections with Ph. damselae subsp. damselae and Vibrio spp. The sampling was conducted during summer and autumn in water temperature between $20-26^{\circ} \mathrm{C}$, in the same range with the outbreaks in the Aegean Sea. A. veronii has also been reported in diseased rainbow trout farmed in the Black Sea and in the Aegean Sea [42]. Fish transfers between farms located in the Black Sea and the Aegean regions could explain the establishment of the pathogen in the latter, however this should be confirmed in a future study using molecular epidemiological methods.

Three phenotypic groups can be described based on motility and pigment production: a) The West Aegean Sea, rarely isolated strains non-motile, non-pigment producing, b) the West Aegean Sea strains motile and pigment-producing, and c) the East Aegean Sea isolates motile and I-pigment-producing. Typical biochemical properties of Aeromonas spp., similar to positive catalase and oxidase reactions, inability to produce acid from xylose, absence of urease, and fermentation of D-glucose were evident for all isolates from seabass [43]. Production of acid from D-arabitol was evident for $47 / 50$ isolates, only few grew in salinity over $4 \% \mathrm{NaCl}$, while trehalose fermentation was evident mainly for the western ones. Despite the lack of motility (NS and NS 13), pigment production (western isolates), and negative indole reaction (all seabass isolates) that are characteristics of $A$. salmonicida [44], all seabass isolates 
were negative for fermentation of L-arabinose and salicin which are characteristics of the $A$. sobria species complex [43]. In the A. sobria species complex, sucrose fermentation (all isolates) is characteristic for $A$. veronii and among the species' biovarieties negative ODC reaction (all except for BIOO50A) is characteristic of $A$. veronii bv. sobria $[43,45]$. It is worth mentioning that indole negative $A$. veronii was reported in both cases of occurrence of the species in diseased seabass mentioned before; in Italy (strains Ae4 and Ae59) [27], and in the Black Sea [41]. Few pigment-producing isolates of A. veronii were also reported in [27]. The brown pigment produced by western strains seems to be pyomelanin which is produced by the tyrosine metabolism pathway [46]. The mechanism of pyomelanin production as well as its importance as competitive advantage [47] for $A$. veronii is the subject of a parallel study of our group (manuscript in preparation).

Biochemically, the only common characteristic among seabass strains was the negative indole reaction which was also evident in other studies $[27,41]$. Whether this is an adaptation that gives advantage to these $A$. veronii strains compared to other aeromonads or other common marine pathogens, has to be investigated as long as indole has been correlated to key aspects of bacterial physiology like drug resistance, biofilm formation, and virulence [48]. For example, non-indole-producing bacteria use diverse oxygenases, which degrade indole from other species producing derivatives implicated in bacterial competition [48].

The resistance to ampicillin (penicillins) together with first generation cephalosporins is genetically encoded in aeromonads [49]. Two beta-lactamase genes were found in the genomes that could justify the ampicillin-resistant phenotype. However, the seabass strains studied here were susceptible to all the other registered for use in aquaculture antibiotics tested. Acquired resistance to antibiotics, e.g., tetracycline, oxolinic acid and flumequine has been reported in aeromonads in aquaculture systems $[50,51]$. Thus, one assumption would be that the multiple susceptibility detected here for $A$. veronii indicates a relatively recent appearance of the species in the Aegean Sea or a more rationale use of antibiotics according to the best practices in the Greek aquaculture industry. In any case, the species has been reported in seabass approximately in the last decade.

Regardless of the phenotypic divergence and the West/East pattern of biochemical diversification shown in cluster analysis, the western-eastern seabass isolates were almost indistinguishable by the majority of the genetic markers used for identification. This was also seen in the phylogenetic analyses in which the strain Ae4 isolated from diseased seabass in Italy showed $0 \%$ divergence from the seabass isolates in the Aegean Sea while strain, e.g., XU 1 from X. helleri was distinct. At the genomic level, high genomic similarity was observed as shown from Ortho-ANI values. The SNPs analysis was consistent with the patterns of phenotypic and geographic origin diversification. Despite the difference in isolation time, the non-motile, non-pigment producing western strains were closer to each other compared with the motile, pigment-producing ones. The same was evident also for the eastern strains (motile, non-pigment producing). The West/East pattern was clearly demonstrated as the difference among strains of different areas that was at least one order of magnitude higher than among strains of the same area. Divergence among $A$. veronii seabass isolates were also at least one order of magnitude higher than the ones reported in A. salmonicida subsp. salmonicida isolated from fresh and seawater farms of trout in Denmark which had a time gap of isolation of approximately 30 years [30].

While for A. salmonicida, host related homogeneity among subpopulations of strains has been proposed in various cases using different methodologies [52], the situation described for A. veronii here might be more complicated as also reported elsewhere [53]. Despite the fact that the particular strains of the species affected only seabass and not seabream nor other species farmed in neighboring cages [9], zebrafish was a successful model for the pathogenicity assay as long as mortality reached $100 \%$ within $48 \mathrm{~h}$ post challenge, at higher, however, doses from the respective needed for seabass [9]. High genomic similarity as observed here has been reported for virulent strains of $A$. hydrophila of the same ST which showed $99.81 \%-100 \%$ similarity in ANI values despite their distant geographic origin (USA, China), isolation source (fish and soil) and time of isolation (1989-2010) [54]. Furthermore, the divergence among western-eastern isolates through SNPs analysis is suggestive of independent 
evolutionary routes of the pathogen in the two sides of the Aegean Sea at least for the last decade that have been detected and isolated. Whether there is a common indole negative ancestor, or this is a case of convergent evolution with adaptive advantage for the pathogen to a new environment, e.g., marine environment, needs further investigation. It should be noted that pathogenic mesophilic aeromonads are mostly found in environments of lower salinity. Additionally, the host range of the pathogen is not defined yet and host physiology should be taken under consideration for possible vulnerability to bacterial pathogens or groups of pathogenic taxa.

The outer membrane proteins were studied as long as they are related to virulence and pathogenicity involving in the attachment and invasion of bacteria to the host. Many known OMPs have been tested as vaccine candidates as they have strong immunogenic effects. The outer membrane protein $\mathrm{W}$ has been shown to be highly conserved among Aeromonas spp. but has also homology with the OmpW of other taxa [55]. Common carp (Cyprinus carpio) intraperitoneally vaccinated and rohu (Labeo rohita) orally vaccinated with recombinant OmpW from A. hydrophila produced antibody titers and showed higher relative percent survival (RPS\%) compared to the control groups following challenge tests [56,57]. Recombinant protein OmpC (general porin family), from A. hydrophila induced immune response in mice [58]. The porin CDS-2 from strain VCK 1 showed $84 \%$ similarity in gene sequence (HF546053) and 87\% similarity with protein OmpC of A. hydrophila (EUS112) [58]. Both OmpW and OmpC were highly conserved among the seabass isolates and therefore could be considered as good candidates for vaccine development.

Other highly conserved membrane proteins among seabass isolates were the porins OmpA which are members of the well-studied OmpA protein family with key role in bacterial pathogenicity [59]. In $A$. veronii from the intestinal tract of carp, two tandem homologues (OmpAI and OmpAII) have been reported and the proteins were related to adhesion of the bacterium to the surface of the intestinal tract of common carp [60]. Here, these homologues corresponded to OmpA porins CDS-1 and CDS-2 and were found tandem with a third homologue (hypothetical CDS-8) with total protein similarity in this group of three homologues $>50 \%$. Comparison with sequences reported from carp (AB290200), OmpAI showed $92 \%$ similarity to OmpA porin-2 while OmpAII 99\% similarity to OmpA porin-1 from seabass. This was the highest similarity of OmpAI and OmpAII from carp when comparing to the other seabass homologues of OmpA-porins. An oral recombinant vaccine with Lactobacillus casei expressing the OmpAI induced immune response and protection against challenge with $A$. veronii in common carp [61].

Few outer membrane proteins varied significantly among seabass isolates in the two sides of the Aegean like maltoporin LamB and S-layer. Both of these membrane substances have been studied and are capable to induce immune response and protection in fish [62-64]. Whether these differences are significant in the development of an $A$. veronii vaccine for seabass has to be further investigated. In terms of strain selection for the development of a bacterin vaccine for the Aegean Sea, a bivalent preparation containing eastern and western strains would be worth trying. Protein distances among seabass strains and strains B565 and XU 1 indicated that at least some proteins were highly conserved among them. This should be further investigated including more $A$. veronii genomes from different hosts and isolation sources in order to detect for instance possible host-related similarities or highly conserved proteins that could serve as antigens for recombinant vaccines for $A$. veronii.

The coverage of the GIs in the genomes of the seabass strains $(>10 \%)$ laid in the higher part of the range described for marine bacteria (3\%-12\%) [65] where in the $50 \%$ of the studied genomes the GI coverage was approximately 3\%. Mobile elements are important for bacterial evolution as they often hand in virulence factors and fitness features. Preliminary analysis detected virulence factors similar to the genes of the type III secretion system in the seabass' GIs as described elsewhere [66]. In addition, the analogy of prophages per genome detected in the current study, although not intact, is mentioned before in another species of the genus, A hydrophila $[54,67,68]$. Prophage genes are widely distributed within the aeromonads $[69,70]$, but in the course of evolution there is a constant process of losing and 
acquiring such genetic material. Further analysis is needed in order to study the relationship among GIs' size and composition and prophage occurrence to the pathogenicity of the A. veronii studied herein.

One of our aims was to clarify if the phenotypic variability of the strains that is the presence and absence of the polar flagellum imposed a difference in the virulence of the bacteria. The non-motile strains had slightly lower LD50, when intraperitoneally injected, which can be due to the fact that the lack of flagella favors them. The flagella are major antigenic elements and the presence of both flagellated and non-flagellated bacteria within a species and also the switch from the one state to the other happens to pathogens and environmental isolates [71,72]. The flagella are strictly regulated structures and they are not formed or do not function if one of the motility genes is missing [73,74] or is non-functional [75]. Between the four genes that differed among the strains, the flgT is more important for the stability and the secretion of the flagellum. The mutants of A. hydrophila with flgT gene deleted had no flagellum [76] contrary to the deletion of the fliS that resulted in phenotypes with reduced motility in Y. pseudotuberculosis [77].

The type II and III secretion systems, prominent structures for the protein transport through the cell envelope, were conserved in all nine strains. There were three clusters of genes of the T3SS and one of the T2SS, containing the components of the apparatuses. The T3SS is considered key factor for the infection mechanism of $A$ veronii bv. sobria [78]. Its function is linked to the resistance of the bacteria to the immune response of the host [79]. In addition, the T2SS participates in the translocation of toxins and assemblage of the type IV pili in the outer membrane [80]. The type VI secretion system was not detected in the strains of West Aegean Sea and the lack of the cluster was a considerable difference. The system is significant for intrabacterial communication and competition but it is also a dominance mechanism within the gut environment [81-83]. However, its absence has been reported again in pathogens of the genus [54,84] and in Bacteroides fragilis the presence of the system varied among strains occupying the same niche [81], which is similar to our case. To sum up, it seems that the first two functional secretion systems are more crucial than the lack of the latter, considering that the strains caused similar pathogenicity in the in vivo studies.

Other genes detected are a set of common exotoxins for aeromonads, including hemolytic enzymes, and iron-binding and transport genes. The $A$. veronii strains exhibit intense hemolytic activity and they are adapted to fish blood causing greater hemolytic effect than in mammal blood, as shown in the previous study [9]. There are many related genes inbuilt in the genome of the strains similar to hemolysins, hemagglutins, the TonB-ExbB-ExbD iron-binding transport system, and iron uptake regulation genes such as the FUR transcriptional factor that justify their virulence. An important difference in the strains of West Aegean Sea compared to the East Aegean ones, is that they have two fragments of aerolysin family toxin due to the presence of an integrase. Aerolysin is responsible for the total osmotic lysis of blood cells and is a major virulence factor of the species. In a recent study of A. veronii, the deletion of aerolysin resulted in a rapid loss of virulence of the pathogen and increased survival of the challenged animals [6]. In our study, in vivo virulence using zebrafish as a model is similar, however results from the field suggest that the West Aegean Sea isolates cause significantly higher mortalities to the cultured seabass.

\section{Conclusions}

The results of this study support the existence of a genetically distinct group of Aeromonas veronii bv. sobria strains that causes pathology to farmed European seabass. The bacteria carry most of the known virulence factors that are implicated in the pathogenicity. The spread of the disease observed over the past years in different fish farms in Greece and Turkey is alarming and since the use of antibiotics is being questioned in connection to consumer's safety and environmental impacts, the development of an efficacious vaccine is in urgent need. Towards this direction, the genomic information related to antigenic proteins presented here can establish the basis for a future study. 
Supplementary Materials: The following are available online at http://www.mdpi.com/2076-2607/7/11/504/s1. Figure S1: Phylogenetic relationships between strains from seabass and other Aeromonas spp. according to the topology of NJ analysis for gyrB gene; Table S1: Results on BIOLOG GEN III Microplate; Table S2: Overview of the sequenced strains and their corresponding genome features; Table S3: Assembly statistics of the sequenced strains; Table S4: Assessment of genome assemblies using BUSCO; Table S5: Similarity of strains NS and VCK 1 with other A. veronii strains and Aeromonas species expressed as \% ANI values; Table S6: The outer membrane proteins of seabass strains; Table S7: Virulence factors of seabass strains.

Author Contributions: M.S. conducted analysis, experiments, and drafted the manuscript; A.T. conducted analysis, experiments, and drafted the manuscript; N.D. and P.V. isolated and characterized bacterial strains, and provided field data for pathology; M.P. contributed with virulence experiments; V.H.Q. contributed with bioinformatic analysis; P.K. designed and supervised the study, contributed with bioinformatic analysis, and drafted the manuscript.

Funding: This research received no external funding.

Acknowledgments: We would like to thank Ozge Otgucuoglu, Veterinary in AK-YA Veterinary Clinic, Mugla, Turkey for her contribution to this study as she kindly offered the strain T04-D (isolated from diseased seabass) and the relevant information.

Conflicts of Interest: The authors declare no conflict of interest.

\section{References}

1. Austin, B.; Austin, D.A. Bacterial Fish Pathogens, 5th ed.; Springer: Dordrecht, The Netherlands, 2012; ISBN 978-94-007-4883-5.

2. Beaz-Hidalgo, R.; Figueras, M.J. Molecular Detection and Characterization of Furunculosis and Other Aeromonas Fish Infections. In Health and Environment in Aquaculture; Carvalho, E.D., Ed.; Intech: Rijeka, Croatia, 2012; pp. 97-132, ISBN 978-953-51-0497-1.

3. Rahman, M.; Colque-Navarro, P.; Kühn, I.; Huys, G.; Swings, J.; Möllby, R. Identification and characterization of pathogenic Aeromonas veronii biovar sobria associated with Epizootic Ulcerative Syndrome in fish in Bangladesh. Appl. Environ. Microbiol. 2002, 68, 650-655. [CrossRef] [PubMed]

4. Cai, S.-H.; Wu, Z.-H.; Jian, J.-C.; Lu, Y.-S.; Tang, J.-F. Characterization of pathogenic Aeromonas veronii bv. veronii associated with ulcerative syndrome from chinese longsnout catfish (Leiocassis longirostris Günther). Braz. J. Microbiol. 2012, 43, 382-388. [CrossRef] [PubMed]

5. Zhu, M.; Wang, X.R.; Li, J.; Li, G.Y.; Liu, Z.P.; Mo, Z.L. Identification and virulence properties of Aeromonas veronii bv. sobria isolates causing an ulcerative syndrome of loach Misgurnus anguillicaudatus. J. Fish Dis. 2015, 39, 777-781. [CrossRef] [PubMed]

6. Ran, C.; Qin, C.; Xie, M.; Zhang, J.; Li, J.; Xie, Y.; Wang, Y.; Li, S.; Liu, L.; Fu, X.; et al. Aeromonas veronii and aerolysin are important for the pathogenesis of motile aeromonad septicemia in cyprinid fish. Environ. Microbiol. 2018, 20, 3442-3456. [CrossRef] [PubMed]

7. Takeuchi, H.; Namba, A.; Hori, K.; Kashiwada, S.; Mano, N. Aeromonas veronii biovar sobria associated with mortalities of riverine ayu Plecoglossus altivelis in the Tama river. Fish Pathol. 2018, 53, 86-89. [CrossRef]

8. Sreedharan, K.; Philip, R.; Singh, I.S.B. Characterization and virulence potential of phenotypically diverse Aeromonas veronii isolates recovered from moribund freshwater ornamental fishes of Kerala, India. Antonie van Leeuwenhoek 2013, 103, 53-57. [CrossRef]

9. Smyrli, M.; Prapas, A.; Rigos, G.; Kokkari, C.; Pavlidis, M.; Katharios, P. Aeromonas veronii Infection Associated with High Morbidity and Mortality in Farmed European Seabass Dicentrarchus labrax in the Aegean Sea, Greece. Fish Pathol. 2017, 52, 68-81. [CrossRef]

10. Kong, R.Y.; Pelling, A.; So, C.; Wu, R.S. Identification of Oligonucleotide Primers Targeted at the 16S-23S rDNA Intergenic Spacers for Genus- and Species-specific Detection of Aeromonads. Mar. Pollut. Bull. 1999, 38, 802-808. [CrossRef]

11. Chacon, M.R.; Castro-Escarpulli, G.; Soler, L.; Guarro, J.; Figueras, M.J. A DNA probe specific for Aeromonas colonies. Diagn. Microbiol. Infect. Dis. 2002, 44, 221-225. [CrossRef]

12. Yanez, M.A.; Catalán, V.; Apráiz, D.; Figueras, M.J.; Martínez-Murcia, A.J. Phylogenetic analysis of members of the genus Aeromonas based on gyrB gene sequences. Int. J. Syst. Evol. Microbiol. 2003, 53, 875-883. [CrossRef] 
13. Thompson, J.D.; Higgins, D.G.; Gibson, T.J. CLUSTAL W: Improving the sensitivity of progressive multiple sequence alignment through sequence weighting, position-specific gap penalties and weight matrix choice. Nucleic Acids Res. 1994, 22, 4673-4680. [CrossRef] [PubMed]

14. Saitou, N.; Nei, M. The neighbor-joining method: A new method for reconstructing phylogenetic trees. Mol. Biol. Evol. 1987, 4, 406-425. [PubMed]

15. Kumar, S.; Stecher, G.; Li, M.; Knyaz, C.; Tamura, K. MEGA X: Molecular Evolutionary Genetics Analysis across computing platforms. Mol. Biol. Evol. 2018, 35, 1547-1549. [CrossRef] [PubMed]

16. Tamura, K.; Nei, M. Estimation of the number of nucleotide substitutions in the control region of mitochondrial DNA in humans and chimpanzees. Mol. Biol. Evol. 1993, 10, 512-526.

17. Katharios, P.; Kokkari, C.; Dourala, N.; Smyrli, M. First report of Edwardsiellosis in cage-cultured sharpsnout sea bream, Diplodus puntazzo from the Mediterranean. BMC Vet. Res. 2015, 11, 155. [CrossRef]

18. Bauer, A.W.; Kirby, W.M.; Sherris, J.C.; Turck, M. Antibiotic susceptibility testing by a standardized single disk method. Tech. Bull. Regist. Med. Technol. Am. Soc. Clin. Pathol. Regist. Med. Technol. 1966, 36, 49-52. [CrossRef]

19. CLSI. Performance Standards for Antimicrobial Susceptibility Testing. CLSI Documnet M100S. Available online: https://clsi.org/media/1469/m100s27_sample.pdf (accessed on 25 July 2019).

20. CLSI. Methods for Antimicrobial Dilution and Disk Susceptibility Testing of Infrequently Isolated or Fastidious Bacteria. Approved Guideline. CLSI Document M45-A2. Available online: https://mycourses. aalto.fi/pluginfile.php/835185/mod_resource/content/1/CLSI_M45-A2.pdf (accessed on 25 July 2019).

21. Zimin, A.V.; Marçais, G.; Puiu, D.; Roberts, M.; Salzberg, S.L.; Yorke, J.A. The MaSuRCA genome assembler. Bioinformatics 2013, 29, 2669-2677. [CrossRef]

22. Simão, F.A.; Waterhouse, R.M.; Ioannidis, P.; Kriventseva, E.V.; Zdobnov, E.M. BUSCO: Assessing genome assembly and annotation completeness with single-copy orthologs. Bioinformatics 2015, 31, 3210-3212. [CrossRef]

23. Waterhouse, R.M.; Seppey, M.; Simao, F.A.; Manni, M.; Ioannidis, P.; Klioutchnikov, G.; Kriventseva, E.V.; Zdobnov, E.M. BUSCO applications from quality assessments to gene prediction and phylogenomics. Mol. Biol. Evol. 2018, 35, 543-548. [CrossRef]

24. Tatusova, T.; DiCuccio, M.; Badretdin, A.; Chetvernin, V.; Nawrocki, E.P.; Zaslavsky, L.; Lomsadze, A.; Pruitt, K.D.; Borodovsky, M.; Ostell, J. NCBI prokaryotic genome annotation pipeline. Nucleic Acids Res. 2016, 44, 6614-6624. [CrossRef]

25. Aziz, R.K.; Bartels, D.; Best, A.A.; DeJongh, M.; Disz, T.; Edwards, R.A.; Formsma, K.; Gerdes, S.; Glass, E.M.; Kubal, M.; et al. The RAST Server: Rapid annotations using subsystems technology. BMC Genom. 2008, 9, 75. [CrossRef] [PubMed]

26. Wattam, A.R.; Abraham, D.; Dalay, O.; Disz, T.L.; Driscoll, T.; Gabbard, J.L.; Gillespie, J.J.; Gough, R.; Hix, D.; Kenyon, R.; et al. PATRIC, the bacterial bioinformatics database and analysis resource. Nucleic Acids Res. 2014, 42, D581-D591. [CrossRef] [PubMed]

27. Martino, M.E.; Fasolato, L.; Montemurro, F.; Rosteghin, M.; Manfrin, A.; Patarnello, T.; Novelli, E.; Cardazzo, B. Determination of Microbial Diversity of Aeromonas Strains on the Basis of Multilocus Sequence Typing, Phenotype, and Presence of Putative Virulence Genes. Appl. Environ. Microbiol. 2011, 77, 4986-5000. [CrossRef] [PubMed]

28. Jolley, K.A.; Bray, J.E.; Maiden, M.C.J. Open-access bacterial population genomics: BIGSdb software, the PubMLST.org website and their applications. Wellcome Open Res. 2018, 3, 124. [CrossRef] [PubMed]

29. Lee, I.; Kim, Y.O.; Park, S.C.; Chun, J. OrthoANI: An improved algorithm and software for calculating average nucleotide identity. Int. J. Syst. Evol. Microbiol. 2016, 66, 1100-1103. [CrossRef]

30. Bartkova, S.; Leekitcharoenphon, P.; Aarestrup, F.M.; Dalsgaard, I. Epidemiology of Danish Aeromonas salmonicida subsp. salmonicida in Fish Farms Using Whole Genome Sequencing. Front. Microbiol. 2017, $8,2411$.

31. Leekitcharoenphon, P.; Kaas, R.S.; Thomsen, M.C.F.; Friis, C.; Rasmussen, S.; Aarestrup, F.M. snpTree - a web-server to identify and construct SNP trees from whole genome sequence data. BMC Genom. 2012, 13, S6. [CrossRef]

32. Kaas, R.S.; Leekitcharoenphon, P.; Aarestrup, F.M.; Lund, O. Solving the Problem of Comparing Whole Bacterial Genomes across Different Sequencing Platforms. PLoS ONE 2014, 9, e104984. [CrossRef] 
33. Yu, N.Y.; Wagner, J.R.; Laird, M.R.; Melli, G.; Rey, S.; Lo, R.; Dao, P.; Sahinalp, S.C.; Ester, M.; Foster, L.J.; et al. PSORTb 3.0: Improved protein subcellular localization prediction with refined localization subcategories and predictive capabilities for all prokaryotes. Bioinformatics 2010, 26, 1608-1615. [CrossRef]

34. Almagro Armenteros, J.J.; Tsirigos, K.D.; Sønderby, C.K.; Petersen, T.N.; Winther, O.; Brunak, S.; von Heijne, G.; Nielsen, H. SignalP 5.0 improves signal peptide predictions using deep neural networks. Nat. Biotechnol. 2019, 37, 420-423. [CrossRef]

35. Tsirigos, K.D.; Peters, C.; Shu, N.; Kall, L.; Elofsson, A. The TOPCONS web server for consensus prediction of membrane protein topology and signal peptides. Nucleic Acids Res. 2015, 43, W401-W407. [CrossRef] [PubMed]

36. Tsirigos, K.D.; Elofsson, A.; Bagos, P.G. PRED-TMBB2: Improved topology prediction and detection of beta-barrel outer membrane proteins. Bioinformatics 2016, 32, i665-i671. [CrossRef] [PubMed]

37. Dhillon, B.K.; Laird, M.R.; Shay, J.A.; Winsor, G.L.; Lo, R.; Nizam, F.; Pereira, S.K.; Waglechner, N.; McArthur, A.G.; Langille, M.G.I.; et al. IslandViewer 3: More flexible, interactive genomic island discovery, visualization and analysis. Nucleic Acids Res. 2015, 43, W104-W108. [CrossRef] [PubMed]

38. Arndt, D.; Grant, J.R.; Marcu, A.; Sajed, T.; Pon, A.; Liang, Y.; Wishart, D.S. PHASTER: A better, faster version of the PHAST phage search tool. Nucleic Acids Res. 2016, 44, W16-W21. [CrossRef]

39. Darling, A.C.E.; Mau, B.; Blattner, F.R.; Perna, N.T. Mauve: Multiple alignment of conserved genomic sequence with rearrangements. Genome Res. 2004, 14, 1394-1403. [CrossRef]

40. Jia, B.; Raphenya, A.R.; Alcock, B.; Waglechner, N.; Guo, P.; Tsang, K.K.; Lago, B.A.; Dave, B.M.; Pereira, S.; Sharma, A.N.; et al. CARD 2017: Expansion and model-centric curation of the comprehensive antibiotic resistance database. Nucleic Acids Res. 2017, 45, D566-D573. [CrossRef]

41. Uzun, E.; Ogut, H. The isolation frequency of bacterial pathogens from sea bass (Dicentrarchus labrax) in the Southeastern Black Sea. Aquaculture 2015, 437, 30-37. [CrossRef]

42. Onuk, E.; Findik, A.; Turk, N.; Altun, S.; Korun, J.; Özer, S.; Avsever, M.; Ciftci, A. Molecular identification and determination of some virulence genes of Aeromonas spp. in fish and water from Turkish coastal regions. Rev. Med. Vet. 2012, 164.

43. Abbott, S.L.; Cheung, W.K.W.; Janda, J.M. The Genus Aeromonas: Biochemical Characteristics, Atypical Reactions, and Phenotypic Identification Schemes. J. Clin. Microbiol. 2003, 41, 2348-2357. [CrossRef]

44. Martin-Carnahan, A.; Joseph, S.W. Family Aeromonadaceae. In Bergey's Manual@of Systematic Bacteriology, Volume 2: The Proteobacteria, Part B: The Gammaproteobacteria; Springer: Dordrecht, The Netherlands, 2005; pp. 556-580.

45. Colston, S.M.; Fullmer, M.S.; Beka, L.; Lamy, B.; Peter Gogarten, J.; Graf, J. Bioinformatic genome comparisons for taxonomic and phylogenetic assignments using Aeromonas as a test case. MBio 2014, 5, e02136-14. [CrossRef]

46. Chatfield, C.H.; Cianciotto, N.P. The Secreted Pyomelanin Pigment of Legionella pneumophila Confers Ferric Reductase Activity. Infect. Immun. 2007, 75, 4062-4070. [CrossRef] [PubMed]

47. Nosanchuk, J.D.; Casadevall, A. Impact of melanin on microbial virulence and clinical resistance to antimicrobial compounds. Antimicrob. Agents Chemother. 2006, 50, 3519-3528. [CrossRef] [PubMed]

48. Lee, J.-H.; Lee, J. Indole as an intercellular signal in microbial communities. FEMS Microbiol. Rev. 2010, 34, 426-444. [CrossRef] [PubMed]

49. Janda, J.M.; Abbott, S.L. The Genus Aeromonas: Taxonomy, Pathogenicity, and Infection. Clin. Microbiol. Rev. 2010, 23, 35-73. [CrossRef]

50. Nawaz, M.; Sung, K.; Khan, S.A.; Khan, A.A.; Steele, R. Biochemical and Molecular Characterization of Tetracycline-Resistant Aeromonas veronii Isolates from Catfish. Appl. Environ. Microbiol. 2006, 72, 6461-6466. [CrossRef]

51. Scarano, C.; Piras, F.; Virdis, S.; Ziino, G.; Nuvoloni, R.; Dalmasso, A.; De Santis, E.P.L.; Spanu, C. Antibiotic resistance of Aeromonas ssp. strains isolated from Sparus aurata reared in Italian mariculture farms. Int. J. Food Microbiol. 2018, 284, 91-97. [CrossRef]

52. Menanteau-Ledouble, S.; Kumar, G.; Saleh, M.; El-Matbouli, M. Aeromonas salmonicida: Updates on an old acquaintance. Dis. Aquat. Organ. 2016, 120, 49-68. [CrossRef]

53. Silver, A.C.; Williams, D.; Faucher, J.; Horneman, A.J.; Gogarten, J.P.; Graf, J. Complex Evolutionary History of the Aeromonas veronii Group Revealed by Host Interaction and DNA Sequence Data. PLoS ONE 2011, 6, e16751. [CrossRef] 
54. Pang, M.; Jiang, J.; Xie, X.; Wu, Y.; Dong, Y.; Kwok, A.H.Y.; Zhang, W.; Yao, H.; Lu, C.; Leung, F.C.; et al. Novel insights into the pathogenicity of epidemic Aeromonas hydrophila ST251 clones from comparative genomics. Sci. Rep. 2015, 5, 9833. [CrossRef]

55. Maiti, B.; Raghunath, P.; Karunasagar, I.; Karunasagar, I. Cloning and expression of an outer membrane protein OmpW of Aeromonas hydrophila and study of its distribution in Aeromonas spp. J. Appl. Microbiol. 2009, 107, 1157-1167. [CrossRef]

56. Maiti, B.; Shetty, M.; Shekar, M.; Karunasagar, I.; Karunasagar, I. Evaluation of two outer membrane proteins, Aha1 and OmpW of Aeromonas hydrophila as vaccine candidate for common carp. Vet. Immunol. Immunopathol. 2012, 149, 298-301. [CrossRef] [PubMed]

57. Dubey, S.; Avadhani, K.; Mutalik, S.; Sivadasan, S.M.; Maiti, B.; Paul, J.; Girisha, S.K.; Venugopal, M.N.; Mutoloki, S.; Evensen, Ø.; et al. Aeromonas hydrophila OmpW PLGA Nanoparticle Oral Vaccine Shows a Dose-Dependent Protective Immunity in Rohu (Labeo rohita). Vaccines 2016, 4, 21. [CrossRef] [PubMed]

58. Yadav, S.K.; Meena, J.K.; Sharma, M.; Dixit, A. Recombinant outer membrane protein C of Aeromonas hydrophila elicits mixed immune response and generates agglutinating antibodies. Immunol. Res. 2016, 64, 1087-1099. [CrossRef] [PubMed]

59. Confer, A.W.; Ayalew, S. The OmpA family of proteins: Roles in bacterial pathogenesis and immunity. Vet. Microbiol. 2013, 163, 207-222. [CrossRef] [PubMed]

60. Namba, A.; Mano, N.; Takano, H.; Beppu, T.; Ueda, K.; Hirose, H. OmpA is an adhesion factor of Aeromonas veronii, an optimistic pathogen that habituates in carp intestinal tract. J. Appl. Microbiol. 2008, 105, 1441-1451. [CrossRef]

61. Zhang, D.-X.; Kang, Y.-H.; Chen, L.; Siddiqui, S.A.; Wang, C.-F.; Qian, A.-D.; Shan, X.-F. Oral immunization with recombinant Lactobacillus casei expressing OmpAI confers protection against Aeromonas veronii challenge in common carp, Cyprinus carpio. Fish Shellfish Immunol. 2018, 72, 552-563. [CrossRef]

62. Khushiramani, R.M.; Maiti, B.; Shekar, M.; Girisha, S.K.; Akash, N.; Deepanjali, A.; Karunasagar, I.; Karunasagar, I. Recombinant Aeromonas hydrophila outer membrane protein 48 (Omp48) induces a protective immune response against Aeromonas hydrophila and Edwardsiella tarda. Res. Microbiol. 2012, 163, $286-291$. [CrossRef]

63. De Santana Lacerda, I.P.; Goncalves, Y.S.; de Oliveira ST, L.; Demarqui, F.N.; Krewer CD, C.; Gouveia, G.V.; Felix, W.P.; Costa, M.M. Efficacy of Aeromonas hydrophila S-layer bacterins with different protein profiles as a vaccine in Nile tilapia (Oreochromis niloticus). Afr. J. Microbiol. Res. 2015, 9, 1770-1777.

64. Poobalane, S.; Thompson, K.D.; Ardo, L.; Verjan, N.; Han, H.-J.; Jeney, G.; Hirono, I.; Aoki, T.; Adams, A. Production and efficacy of an Aeromonas hydrophila recombinant S-layer protein vaccine for fish. Vaccine 2010, 28, 3540-3547. [CrossRef]

65. Fernández-Gómez, B.; Fernàndez-Guerra, A.; Casamayor, E.O.; González, J.M.; Pedrós-Alió, C.; Acinas, S.G. Patterns and architecture of genomic islands in marine bacteria. BMC Genom. 2012, 13, 347. [CrossRef]

66. Puhar, A.; Sansonetti, P.J. Type III secretion system. Curr. Biol. 2014, 24, R784-R791. [CrossRef] [PubMed]

67. Awan, F.; Dong, Y.; Liu, J.; Wang, N.; Mushtaq, M.H.; Lu, C.; Liu, Y. Comparative genome analysis provides deep insights into Aeromonas hydrophila taxonomy and virulence-related factors. BMC Genom. 2018, 19, 712. [CrossRef] [PubMed]

68. Hossain, M.J.; Waldbieser, G.C.; Sun, D.; Capps, N.K.; Hemstreet, W.B.; Carlisle, K.; Griffin, M.J.; Khoo, L.; Goodwin, A.E.; Sonstegard, T.S.; et al. Implication of Lateral Genetic Transfer in the Emergence of Aeromonas hydrophila Isolates of Epidemic Outbreaks in Channel Catfish. PLoS ONE 2013, 8, e80943. [CrossRef] [PubMed]

69. Emond-Rheault, J.-G.; Vincent, A.T.; Trudel, M.V.; Brochu, F.; Boyle, B.; Tanaka, K.H.; Attéré, S.A.; Jubinville, É.; Loch, T.P.; Winters, A.D.; et al. Variants of a genomic island in Aeromonas salmonicida subsp. salmonicida link isolates with their geographical origins. Vet. Microbiol. 2015, 175, 68-76. [PubMed]

70. Dziewit, L.; Radlinska, M. Two novel temperate bacteriophages co-existing in Aeromonas sp. ARM81 characterization of their genomes, proteomes and DNA methyltransferases. J. Gen. Virol. 2016, 97, 2008-2022. [CrossRef] [PubMed]

71. Spöring, I.; Felgner, S.; Preuße, M.; Eckweiler, D.; Rohde, M.; Häussler, S.; Weiss, S.; Erhardt, M. Regulation of Flagellum Biosynthesis in Response to Cell Envelope Stress in Salmonella enterica Serovar Typhimurium. MBio 2018, 9. [CrossRef] [PubMed] 
72. Rossi, E.; Paroni, M.; Landini, P. Biofilm and motility in response to environmental and host-related signals in Gram negative opportunistic pathogens. J. Appl. Microbiol. 2018. [CrossRef]

73. Evans, L.D.B.; Hughes, C.; Fraser, G.M. Building a flagellum outside the bacterial cell. Trends Microbiol. 2014, 22, 566-572. [CrossRef]

74. Liu, R.; Ochman, H. Stepwise formation of the bacterial flagellar system. Proc. Natl. Acad. Sci. USA 2007, 104, 7116-7121. [CrossRef]

75. Altarriba, M.; Merino, S.; Gavín, R.; Canals, R.; Rabaan, A.; Shaw, J.G.; Tomás, J.M. A polar flagella operon (flg) of Aeromonas hydrophila contains genes required for lateral flagella expression. Microb. Pathog. 2003, 34, 249-259. [CrossRef]

76. Merino, S.; Tomás, J.M. The FlgT protein is involved in Aeromonas hydrophila polar flagella stability and not affects anchorage of lateral flagella. Front. Microbiol. 2016, 7, 1-15. [CrossRef] [PubMed]

77. Xu, S.; Peng, Z.; Cui, B.; Wang, T.; Song, Y.; Zhang, L.; Wei, G.; Wang, Y.; Shen, X. FliS modulates FlgM activity by acting as a non-canonical chaperone to control late flagellar gene expression, motility and biofilm formation in Yersinia pseudotuberculosis. Environ. Microbiol. 2014, 16, 1090-1104. [CrossRef] [PubMed]

78. Chacón, M.R.; Soler, L.; Groisman, E.A.; Guarro, J.; Figueras, M.J. Type III secretion system genes in clinical Aeromonas isolates. J. Clin. Microbiol. 2004, 42, 1285-1287. [CrossRef] [PubMed]

79. Silver, A.C.; Kikuchi, Y.; Fadl, A.A.; Sha, J.; Chopra, A.K.; Graf, J. Interaction between innate immune cells and a bacterial type III secretion system in mutualistic and pathogenic associations. Proc. Natl. Acad. Sci. USA 2007, 104, 9481-9486. [CrossRef]

80. Marden, J.N.; McClure, E.A.; Beka, L.; Graf, J. Host Matters: Medicinal Leech Digestive-Tract Symbionts and Their Pathogenic Potential. Front. Microbiol. 2016, 7. [CrossRef]

81. Wexler, A.G.; Bao, Y.; Whitney, J.C.; Bobay, L.-M.; Xavier, J.B.; Schofield, W.B.; Barry, N.A.; Russell, A.B.; Tran, B.Q.; Goo, Y.A.; et al. Human symbionts inject and neutralize antibacterial toxins to persist in the gut. Proc. Natl. Acad. Sci. USA 2016, 113, 3639-3644. [CrossRef]

82. Russell, A.B.; Peterson, S.B.; Mougous, J.D. Type VI secretion system effectors: Poisons with a purpose. Nat. Rev. Microbiol. 2014, 12, 137-148. [CrossRef]

83. Logan, S.L.; Thomas, J.; Yan, J.; Baker, R.P.; Shields, D.S.; Xavier, J.B.; Hammer, B.K.; Parthasarathy, R. The Vibrio cholerae type VI secretion system can modulate host intestinal mechanics to displace gut bacterial symbionts. Proc. Natl. Acad. Sci. USA 2018, 115, E3779-E3787. [CrossRef]

84. Gauthier, J.; Vincent, A.T.; Charette, S.J.; Derome, N. Strong Genomic and Phenotypic Heterogeneity in the Aeromonas sobria Species Complex. Front. Microbiol. 2017, 8, 2434. [CrossRef] 